\title{
PETROGENESIS AND EVOLUTION OF AN EARLY PROTEROZOIC COLLISIONAL OROGENIC BELT: THE GRANULITE BELT OF LAPLAND AND THE BELOMORIDES (FENNOSCANDIA).
}

\author{
P. BARBEY; J. CONVERT; B. MOREAU; R. CAPDEVILA and J. HAMEURT
}

\begin{abstract}
BERBEY, P.; CONVERT, J.; MOREAU, B.; CAPDEVILA, R. and HAMEURT, J., 1984: Petrogenesis and evolution of an early Proterozoic collisional orogenic belt: The granulite belt of Lapland and the Belomorides (Fennoscandia). Bull. Geol. Soc. Finland 56, Part 1-2, 161-188.

The tectonic and metamorphic pattern of the Precambrian crust exposed in the eastern Baltic Shield is characterized by two adjacent high-grade belts (Tana and Granulite belts) located between the Archean Inari-Kola craton to the east and the South Lapland-Karelia craton to the west.

The Tana belt corresponded to a volcanic sequence (tholeiitic and calcalkaline series) subsequently intruded by various plutonic rocks including the Vaskojoki anorthositic suite. The Granulite belt is interpreted as a flysch-like greywacke-shale sequence (khondalite suite) including impersistent volcanic layers later intruded by several igneous suites of both tholeiitic and calc-alkaline affinity (charnockitic complex). These two former belts constitute the axial part of the Belomorides, an early Proterozoic fold belt. Major parts of this mobile belt surrounding the axial zone are composed of intensely reworked Archean material. The Jatulian volcano-sedimentary formations cover large areas on both sides of the mobile belt. Allowing for their epicontinental nature, their early Proterozoic age $(2.0-2.4 \mathrm{Ga})$ and for their deformation by the $1.9 \mathrm{Ga}$ Karelian event, we suggest that the Jatulian formations belong to the Belomorides.

We propose to re-interpret the Belomorian fold belt in terms of a Wilson cycle as a collisional orogenic belt comprising a geosynclinal basin with oceanic crust (Tana and Granulite belts), an Archean reactivated basement (Belomorian gneisses) and a platform (Jatulian). The Belomorides represent the oldest fold belt in which a suture has been recognized and constitute an intermediate case between an intracontinental mobile belt orogeny and an active plate margin.
\end{abstract}

P. Barbeyi, 2; J. Convert ${ }^{2}$; B. Moreau ${ }^{2} ;$ R. Capdevila ${ }^{2}$ and J. Hameurt ${ }^{2}$ :

I Laboratoire de Pétrologie, Université de Nancy I, B.P. 239, 54506 Vandoeuvre-lés-Nancy Cédex, France.

2 Centre Armoricain d'Etude Structurale des Socles, Université de Rennes, 35042 Rennes Cédex, France.

\section{Introduction}

The literature abounds in descriptions of rocks of granulite facies but the most prominent occurrences have been reported from Archean and Proterozoic high-grade mobile belts (e.g.
Limpopo, Iforas, Sri Lanka, Madras, Musgrave, Grenville and Lapland). Most of these incorporate diverse lithological units: Supracrustal sequences, layered igneous complexes and reworked older basement gneisses.

Unlike the Phanerozoic granulites thought to 
be formed at each stage of the Wilson cycle (see Windley 1981), opinions are divided as to whether plate tectonic processes were valid in the Precambrian or not. Two controversial models have been proposed to explain the formation of Precambrian high-grade mobile belts. The absence of geosynclinal sediments and volcanics together with the existence of large areas of reactivated basement in many mobile belts have led some authors to conclude that the belts developed by remobilization of a pre-existing crystalline basement. Hence they propose various models for intracontinental mobile belts and aulacogens (Shackelton 1973; Sutton and Watson 1974; Katz 1976, 1977; Williams 1977; Barton and Key 1981; Condie 1982) on the basis of the general concept of the »intracontinental or ensialic orogeny» (Kröner 1977, 1981). However, although many Archean and early Proterozoic mobile belts lack any sign of ocean floor spreading, extensive geochemical, petrological and field data support tectonic models of marginal orogenesis involving active plate margin environments and continental collision (Windley and Smith 1976; Tarney and Windley 1977; Hoffman 1980; Martignole 1979; Barbey et al. 1980; Coward 1980; Baragar and Scoates 1981; Raith et al. 1982; Newton and Perkins 1982; Gibb 1983). It is now speculated that the transition to the present-day plate tectonic regime was influenced by changes in crustal growth processes; interpretations consistent with plate tectonics have therefore been proposed (Hargraves 1981). Furthermore, a model based on the stability of the oceanic tectosphere has recently been published (Hynes 1982), predicting a gradual but diachronous change with progressive cooling of the mantle from the primeval early Proterozoic orogenies characterized by the development of small ocean basins to modern plate tectonics.

The present paper on the Lapland granulites is an attempt to synthethize the geology of one of the classical examples of a high-grade mobile belt in order to outline the major features that will enable us to constrain and propose a geodynamic model for early Proterozoic crustal evolution.

\section{Geological outline}

The Granulite belt of Lapland (Eskola 1952; Meriläinen 1976) represents only the northern part of a vast high-grade metamorphic belt running southwestwards from the Caledonian fold belt in the north to the shores of the White Sea in the south (Fig. 1). It is part of the early Proterozoic Belomorides fold belt as previously defined by Polkanov and Gerling (1960). Our own observations and recent isotopic dating carried out at the University of Rennes permit us to reconsider the Belomorian geotectonic assemblage and to reinterpret its whole evolution.

The eastern part of the Baltic Shield is made up mainly of the classical Archean granitegneiss-greenstone association, which is particularly well represented in the Kola Peninsula and in Karelia (Gaál et al. 1978; Kratz 1978; Blais et al. 1978; Jahn et al. 1980; Vidal et al. 1980; Auvray et al. 1982; Martin et al. $1983 \mathrm{a}$, 1983 b). Within these two regions, low to highgrade formations of early Proterozoic age (1.9 $-2.4 \mathrm{Ga}$ ) generally occur in elongate structures. We refer the following units to the Belomorides.

(1) Two high-grade metamorphic belts, the Tana and the Granulite belts (Barbey et al. 1980, 1982 b), composed of various supracrustals and intrusives, constitute the axial zone of the Belomorides. They are believed to represent geosynclinal volcanism and sedimentation. Whereas the oldest age recorded in a metagranite of the Tana belt is $2.36 \mathrm{Ga}(\mathrm{U} / \mathrm{Pb}$ method on zircon; Meriläinen 1976), the granulite-facies metamorphic event is clearly dated at 1.9-2.0 Ga (Bernard-Griffiths et al. 1984).

(2) Polycyclic gneisses are extensively distributed on both sides of the axial zone. They are the reactivated part of the wide Archean base- 
Fig. 1. Geological sketch map of the northwestern part of the Baltic Shield. Redrawn after von Gaertner (1964), Bibikova et al. (1973) and Barbey et al. (1980).

1) Undifferentiated Archean basement; 2) Tana belt; 3) Granulite belt; 4) Caledonian fold belt; 5) crosssection of the Figure 2.

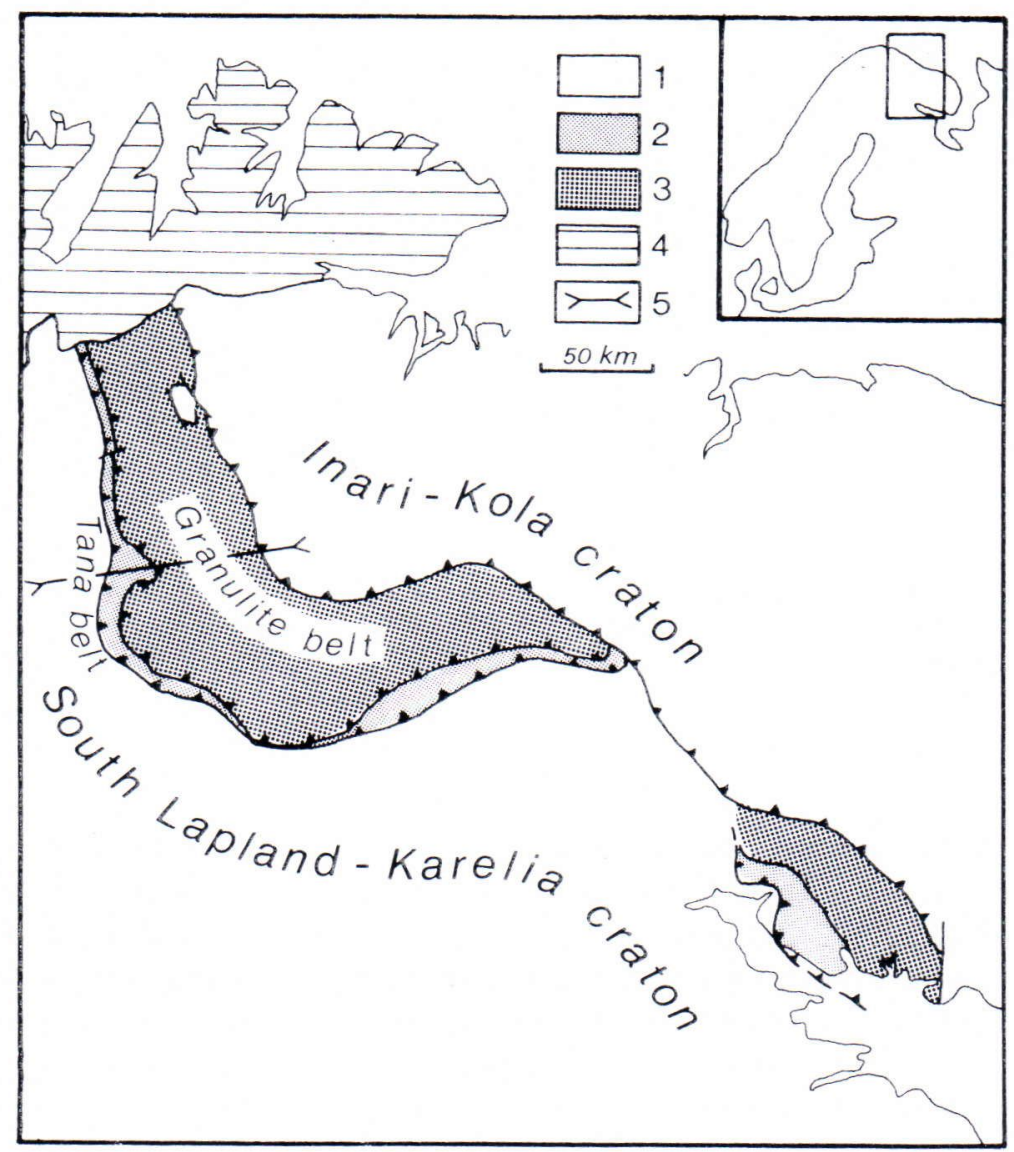

ment of Kola and Karelia and correspond to the Inari-Kola and South Lapland-Karelia cratons (Fig. 1). Their isotopic ages range from $3.10 \mathrm{Ga}$ (Kröner et al. 1981) to $1.90 \mathrm{Ga}$ (Meriläinen 1976; Martin et al. 1983 a and unpubl. results).

(3) The Jatulian formations, whose isotopic ages $(2.0-2.4 \mathrm{Ga})$ overlap those estimated for the Belomorides, comprise continental to epicontinental metavolcanics and metasediments resting unconformably upon the Archean basement in local basin and rift structures in Kola and Karelia (see references in Silvennoinen 1980).

In Finnish Lapland, all these units (from northeast to southwest: Inari-Kola craton,
Granulite belt, Tana belt and South LaplandKarelia craton) are disposed in a major thrustbelt facing SW whose central part is characterized by granulite-grade metamorphism. Note that the granulite facies assemblages extend beyond the Granulite belt into the Tana belt and the Inari-Kola craton (Fig. 2).

\section{The Tana belt}

The Tana formations constitute a narrow belt underlying continuously the western margin of the Granulite belt. They are petrographically and geochemically distinct from the Archean Karasjoki-Kittilä greenstones and were em- 


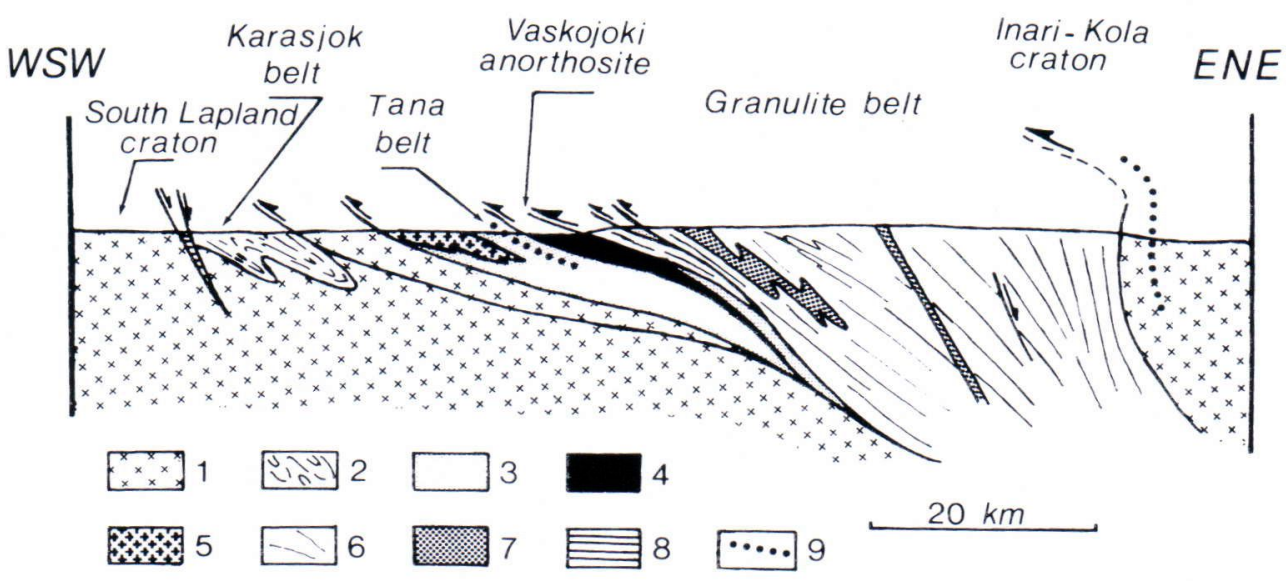

Fig. 2. Synthetic section across the Granulite belt and adjacent units at the latitude of Inari (see location of Figure 1).

1) Undifferentiated Archean basement; 2) Archean greenstone belts; 3) Tana belt; 4) Vaskojoki anorthositic complex; 5) Granites; 6 and 7) Granulite belt (the khondalite suite and the charnockitic complex); 8) Jatulian formations; 9) Granulite facies isograd.

placed and metamorphosed at about 1.9-2.0 $\mathrm{Ga}$ as demonstrated by recent isotopic studies (Bernard-Griffiths et al. 1984). Their metamorphic and tectonic evolution is similar to that of the Granulite belt and will be described later. Two main metamorphic units, one of volcanic and one of plutonic origin, have been distinguished.

\section{The volcanic unit}

This unit consists of a monotonous series of mafic and intermediate amphibolites or granulites (depending on the prevailing metamorphic conditions) alternating in layered sequences centimetres to metres thick and locally interbedded with quartzo-feldspathic gneisses. The main minerals of the granulites which form the eastern part of the belt, are plagioclase (An 3060 ), orthopyroxene (Fs 50-55) and salitic clinopyroxene; the accessories are garnet and hornblende. The amphibolites occur mainly in the western part and sometimes replace granulites in retrograded zones. They are plagioclase (An 45-60) and hornblende-bearing rocks with clinopyroxene, garnet and sphene as typical minor constituents. Quartzo-feldspathic gneisses are leucocratic quartz and plagioclase-rich rocks with garnet in subordinate amounts. Ultramafic bodies (pyroxenites, cortlandites, hornblendites) and intercalations of clearly sedimentary origin (garnet-bearing quartzites and calc-silicate rocks) have also been reported (Meriläinen 1976; Papunen et al. 1977; Hörmann et al. 1980)).

The major element variations in the three main rock groups are typical of igneous geochemistry, as indicated by the appropriate geochemical diagrams, and suggest the existence of three volcanic suites (Fig. 3). The first series is tholeiitic and the second calc-alkaline, but the third series consists only of rhyodacitic and rhyolitic rocks (Table 1).

The tholeiitic series comprises basaltic and andesitic differentiated members $\left(\mathrm{SiO}_{2} \leqslant 63 \%\right)$ characterized by strong iron enrichment $(\mathrm{FeO}$ $\simeq 16 \%$ ) and a moderate increase in $\mathrm{TiO}_{2}$. Samples of basaltic composition correspond to the low-K tholeiites of Pearce's classification (1976) but they cannot be attributed unequivocally to any type of modern basalt. Although in their lack of differentiated products other than 
Fig. 3. $\mathrm{TiO}_{2}$ versus $\mathrm{FeO} * / \mathrm{MgO}$ diagram for the Tana belt volcanic unit (from Barbey et al. 1982 b).

1) Tholeiitic series; 2 ) Calc-alkaline series; 3) Rhyodacitic volcanics; 4) Average rhyodacitic rocks from Hörmann et al. (1980, table 4).

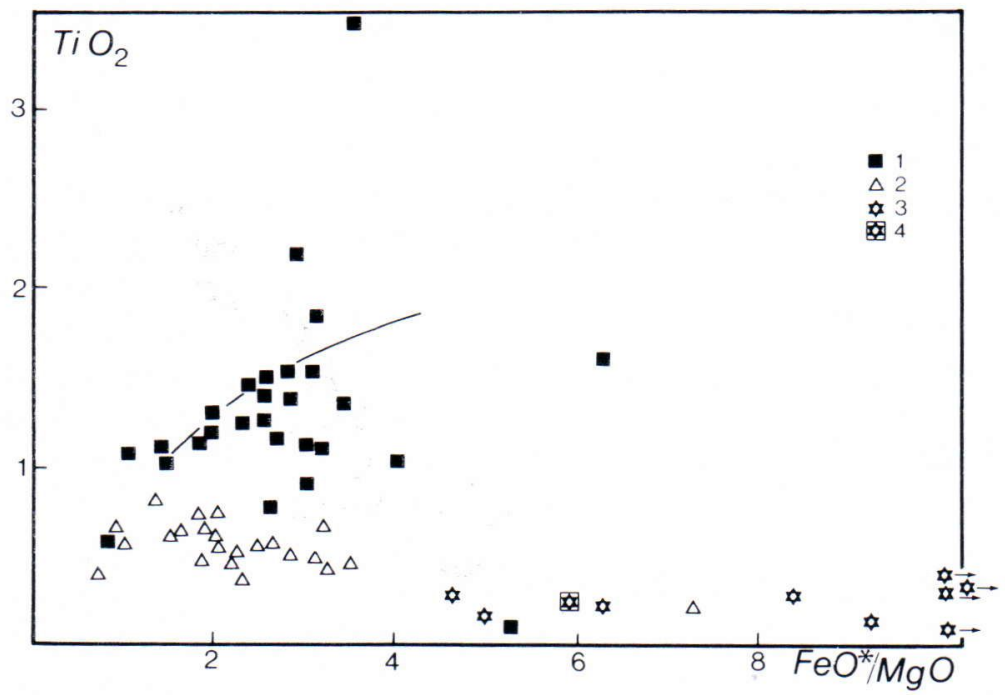

andesites, their $\mathrm{Al}_{2} \mathrm{O}_{3} / \mathrm{TiO}_{2}$ and $\mathrm{CaO} / \mathrm{TiO}_{2}$ ratios and their $\mathrm{Ti}, \mathrm{Ni}$ and $\mathrm{Cr}$ contents, they are suggestive of oceanic tholeiites, the average $\mathrm{Ba}, \mathrm{Th}$ and La values given by Hörmann et al. (1980) and their $\mathrm{Rb}$ and $\mathrm{Sr}$ contents are reminiscent of island arc tholeiites (Jakes and Gill 1970) and clearly indicate enrichment in lithophile elements. Samples of andesitic composition have a low-K content (mean value of $0.8 \mathrm{wt} \%$ ) and $\mathrm{K} / \mathrm{Ti}$ ratios near to unity; they are thus similar to low- $\mathrm{K}$ andesites according to the criteria given by Bailey (1981).

The calc-alkaline series ranges from basaltic to andesitic and dacitic in composition $\left(\mathrm{SiO}_{2}\right.$ $\leqslant 67 \%$ ) and is characterized by a regular decrease in iron and titanium with increasing silica content. The abundances of $\mathrm{K}, \mathrm{Rb}$ and $\mathrm{Sr}$ in the basaltic and andesitic samples are relatively low and similar to those of the tholeiitic series.

The REE distribution in Tana amphibolites

Table 1. Average compositions of the three metavolcanic suites of the Tana belt. Data from Barbey et al. 1982 b. 1) $\left.\mathrm{SiO}_{2} \leqslant 52 \% ; 2\right) \mathrm{SiO}_{2} \leqslant 56 \% ; 3$ ) $\left.\mathrm{SiO}_{2} \leqslant 61 \% ; 4\right) \mathrm{SiO}_{2} \leqslant 67 \%$. (a, b, c, d, e, based respectively on $1,3,5,7$, and 9 samples only).

\begin{tabular}{|c|c|c|c|c|c|c|c|c|c|c|c|c|c|c|}
\hline & \multicolumn{6}{|c|}{ Series I (tholeiitic) } & \multicolumn{7}{|c|}{ Series II (calc-alkaline) } & \multirow{2}{*}{$\begin{array}{c}\text { Series III } \\
\text { (rhyodacitic } \\
\text { rocks) }\end{array}$} \\
\hline & & 1 & & 2 & & 3 & & 1 & 2 & & 3 & & 4 & \\
\hline $\mathrm{n}$ & 16 & & 8 & & 5 & & 5 & & 3 & 9 & & 8 & & 4 \\
\hline $\mathrm{SiO}_{2}$ & 46.94 & $(2.6)$ & 53.47 & $(0.7)$ & 58.40 & $(2.5)$ & 49.09 & $(1.5)$ & $52.85(0.5)$ & 58.90 & $(1.5)$ & 64.63 & $(2.1)$ & $75.54(1.7)$ \\
\hline $\mathrm{Al}_{2} \mathrm{O}_{3}$ & 15.12 & $(1.8)$ & 15.32 & $(1.4)$ & 14.76 & $(1.7)$ & 14.73 & $(1.9)$ & $15.11(1.0)$ & 14.95 & $(0.8)$ & 14.23 & $(0.7)$ & $11.87(0.7)$ \\
\hline $\mathrm{Fe}_{2} \mathrm{O}_{3}$ & 14.73 & $(2.5)$ & 13.81 & $(2.2)$ & 11.15 & $(2.7)$ & 12.29 & $(0.9)$ & $10.75(0.5)$ & 9.75 & $(1.1)$ & 7.40 & $(2.2)$ & $3.52(1.5)$ \\
\hline $\mathrm{MnO}$ & 0.21 & $(0.05)$ & 0.22 & $(0.04)$ & 0.16 & $(0.03)$ & 0.20 & $(0.02)$ & $0.18(0.2)$ & 0.16 & $(0.02)$ & 0.13 & $(0.04)$ & $0.05(0.04)$ \\
\hline $\mathrm{MgO}$ & 6.41 & $(2.4)$ & 3.60 & $(0.9)$ & 2.45 & $(1.1)$ & 8.71 & $(3.5)$ & $6.68(2.1)$ & 3.93 & $(0.6)$ & 2.24 & $(0.9)$ & $0.36(0.3)$ \\
\hline $\mathrm{CaO}$ & 10.89 & (2.3) & 8.02 & $(0.9)$ & 5.85 & $(1.7)$ & 9.70 & $(0.6)$ & $8.12(1.0)$ & 5.15 & $(2.1)$ & 6.06 & (1.1) & $2.89(1.0)$ \\
\hline $\mathrm{Na}_{2} \mathrm{O}$ & 2.28 & $(0.7)$ & 3.33 & $(0.7)$ & 3.90 & $(0.6)$ & 2.61 & $(0.8)$ & $3.47(0.4)$ & 2.73 & $(0.6)$ & 2.95 & $(0.6)$ & $3.57(0.7)$ \\
\hline $\mathrm{K}_{2} \mathrm{O}$ & 0.74 & $(0.4)$ & 0.64 & $(0.1)$ & 1.14 & $(0.4)$ & 0.80 & $(0.3)$ & $1.01(0.3)$ & 0.78 & $(0.4)$ & 0.70 & $(0.5)$ & $0.81 \quad(0.8)$ \\
\hline $\mathrm{TiO}_{2}$ & 1.47 & $(0.7)$ & 1.29 & $(0.2)$ & 1.21 & $(0.3)$ & 0.58 & $(0.1)$ & $0.72(0.1)$ & 0.54 & $(0.09)$ & 0.43 & $(0.2)$ & $0.22(0.08)$ \\
\hline $\mathrm{P}_{2} \mathrm{O}_{5}$ & 0.22 & $(0.1)^{e}$ & 0.29 & $(0.07)^{c}$ & 0.19 & $(0.1)^{b}$ & 0.17 & $(0.1)^{\mathrm{b}}$ & $0.12^{\mathrm{a}}$ & 0.13 & $(0.02)^{\mathrm{d}}$ & 0.17 & $(0.06)^{d}$ & $0.07(0.01)$ \\
\hline
\end{tabular}


and hornblende gneisses given by Hörmann et al. (1980), which probably includes samples of the two volcanic series, shows nearly flat to fractionated patterns. The $\mathrm{La}_{\mathrm{N}} / \mathrm{Yb}_{\mathrm{N}}$ ratios are $0.9-2$ in basalts and $1-3$ in andesites with enrichment factors of 10-40 compared with chondrite.

The rhyodacitic volcanics form locally a bimodal volcanic association with the basalts of the tholeiitic and calc-alkaline series. Their main chemical features are high silica (73$78 \%)$, low potassium $(0.8 \%)$ and low Rb (10 ppm) contents. Their low $\mathrm{Y}$ and $\mathrm{Zr}$ contents and their highly fractionated REE patterns $\left(\mathrm{La}_{\mathrm{N}} /\right.$ $\mathrm{Yb}_{\mathrm{N}}=10-25$ and $\mathrm{La}_{\mathrm{N}}=50$ as in Hörmann et al. 1980) suggest that they are not felsic differentiated products of the former two suites but could constitute a distinct series.

Further studies are needed to establish the tectonic setting of the volcanic unit because available chemical data are still too few and because the relationships between the volcanic series obscured by intense thrusting remain poorly known. Nevertheless, the existence of a local bimodal volcanic association and chemical evidence of crustal contamination of (MORBtype ?) tholeiites are consistent with a continental rifting process (Eichelberger 1978). The original nature of the metasediments (calcareous and argillaceous sandstones) is also compatible with such an interpretation. However, the scarcity of sediments and the lack of alkaline volcanism could be accounted for by the absence of marine inundation and a higher degree of melting in the mantle related to steeper geotherms (mantle-activated rift of Condie 1982).

\section{The plutonic unit}

Three main types of plutonic bodies: anorthosites and related rocks, troctolitic gabbros and granites, were emplaced into the volcanic unit before the evolution of the mobile belt has been completed.

A significant feature of the anorthositic bodies is their location along the major eastward- dipping thrust plane dividing the Tana and Granulite belts. The Vaskojoki massif, which is the only one of an important size, has been investigated in detail by Moreau $(1980,1981)$. Its main characteristics are outlined below.

Small intrusions of troctolites have been reported from Hirvipäät (Sederholm 1916), Mukkapalo (Hörmann et al. 1980), Tsohkavarri and Purnumukka (Barbey 1982). These rocks have been described briefly by Sederholm (1916) and Hörmann et al. (1980).

Granites are mainly located in the vicinity of Repojoki in the southwestern part of the belt. Despite their metamorphic fabric they are clearly different from the rhyodacitic metavolcanics, particularly in their higher $\mathrm{K}$ and $\mathrm{Rb}$ contents (4\% and $150 \mathrm{ppm}$ respectively). Although most of them are of unknown age, one occurrence near Lemmeskäpalo yielded zircon ages of 2.36 $\mathrm{Ga}$ (Meriläinen 1976). This age is similar to the ages of the late Archean granites linked with the greenstone belts of Karelia (Martin and Querre 1984) and could point to granitoids derived from the melting of crustal material at an early stage of the evolution of the Belomorian fold belt.

The Vaskojoki anorthositic complex corresponds to a dome-shaped structure overturned westwards and overlain on its southern side by the Lapland metasedimentary granulites. The planar fabric of the massif is conformable with the regional foliation. It consists of four lithological types, which become gradually more mafic outwards. The rocks include in decreasing order of abundance anorthosites $(\mathrm{M}<$ $10, \mathrm{M}=\%$ mafic minerals) in the central part of the complex, gabbroic anorthosites $(10<\mathrm{M}$ $<22)$, anorthositic gabbros $(22<\mathrm{M}<35)$ and scarce gabbros restricted to the outer zones. The main minerals are plagioclase (An $=55-70$ ) and common hornblende. Clinopyroxene, orthopyroxene, garnet and opaque oxides generally occur in subordinate amounts. The metamorphic evolution deduced from the mineral assemblages is similar to that of the adjacent units 
Table 2. Average compositions of the main lithological types of the Vaskojoki anorthositic complex. Data from Moreau (1981). Standard deviation in brackets.

\begin{tabular}{lcccc}
\hline & Anorthosite & Gabbroic anorthosite & Anorthositic gabbro & Gabbro \\
\hline $\mathrm{n}$ & 12 & 2 & 4 & 8 \\
$\mathrm{SiO}_{2}$ & $50.00(0.3)$ & $52.58(0.7)$ & $47.70(0.5)$ & $48.61(0.6)$ \\
$\mathrm{Al}_{2} \mathrm{O}_{3}$ & $30.18(0.4)$ & $26.64(0.2)$ & $25.77(0.5)$ & $13.99(0.4)$ \\
$\mathrm{Fe}_{2} \mathrm{O}_{3}$ & $1.20(0.1)$ & $3.07(0.1)$ & $5.71(0.1)$ & $16.09(0.5)$ \\
$\mathrm{MnO}$ & $0.25(0.1)$ & $0.52(0.5)$ & $0.08(0.01)$ & $0.21(0.01)$ \\
$\mathrm{MgO}$ & $0.43(0.06)$ & $1.42(0.06)$ & $2.99(0.4)$ & $5.98(0.4)$ \\
$\mathrm{CaO}$ & $13.72(0.2)$ & $10.88(0.5)$ & $12.61(0.2)$ & $9.99(0.2)$ \\
$\mathrm{Na} \mathrm{O}_{2} \mathrm{O}$ & $2.88(0.2)$ & $3.83(0.4)$ & $2.90(0.08)$ & $0.07(0.1)$ \\
$\mathrm{K}_{2} \mathrm{O}$ & $0.25(0.02)$ & $0.48(0.2)$ & $0.44(0.08)$ & $1.63(0.08)$ \\
$\mathrm{TiO}_{2}$ & $0.13(0.01)$ & $0.35(0.09)$ & $0.36(0.04)$ & $0.24(0.02)$ \\
$\mathrm{P}_{2} \mathrm{O}_{5}$ & $0.07(0.01)$ & $0.09(0.01)$ & $0.10(0.3)$ & 8 \\
$\mathrm{n}$ & 13 & 2 & 4 & $8(2)$ \\
$\mathrm{Rb}$ & $\operatorname{tr}$ & $\operatorname{tr}$ & $6(1)$ & $166(10)$ \\
$\mathrm{Sr}$ & $305(9)$ & $593(105)$ & $274(10)$ & $143(12)$ \\
$\mathrm{Zr}$ & $11(3)$ & $42(12)$ & $29(7)$ & $38(4)$ \\
$\mathrm{Y}$ & $\operatorname{tr}$ & $\operatorname{tr}$ & $9(1)$ & $12(1)$ \\
$\mathrm{Nb}$ & $\operatorname{tr}$ & $30(6)$ & $64(15)$ & $95(16)$ \\
$\mathrm{Ni}$ & $15(1)$ & $18(11)$ & $117(75)$ & $66(3)$ \\
$\mathrm{Co}$ & $132(58)$ & $20(8)$ & $80(8)$ & $335(20)$ \\
$\mathrm{V}$ & $19(2)$ & $20(8)$ & $89(23)$ & $152(35)$ \\
$\mathrm{Cr}$ & $9(1)$ & & & \\
\hline
\end{tabular}

and corresponds to the successive stability of the clinopyroxene-garnet and orthopyroxeneplagioclase associations. Major and trace element variations (Table 2), in particular the positive correlation between $\mathrm{Al}, \mathrm{Ca}$ and $\mathrm{Sr}$, and their negative correlations with $\mathrm{Fe}, \mathrm{Mg}, \mathrm{Ti}, \mathrm{Rb}$, $\mathrm{Y}, \mathrm{Zr}, \mathrm{Nb}, \mathrm{Ni}, \mathrm{Co}, \mathrm{V}, \mathrm{Cr}$ and $\mathrm{REE}$, suggest that all the lithological types are comagmatic. A model calculation based on REE shows that the main features of the different rock types can be satisfactorily explained by the fractional crystallization of a parental magma of high-alumina-basalt type (Fig. 4) and probably of mantellic origin $\left(0.7017 \leqslant \mathrm{I}_{\mathrm{Sr}} \leqslant 0.7025\right)$.

The structural, petrographical and chemical data imply that the crystallization and the emplacement of the Vaskojoki anorthositic complex occurred synchronously with the granulite facies metamorphism. We believe this massif rose as a diapiric dome of mantle origin along a major thrust zone during a continental collision (see discussion).

\section{The granulite belt}

The Granulite belt of Lapland is a markedly homogeneous, thick metasedimentary sequence composed mainly of shales and greywackes and including volcanic layers. Termed the khondalite suite, they were later intruded by mafic to intermediate pyroxene-bearing igneous rocks constituting the charnockitic complex. Since detailed description of these two units has been given elsewhere (Barbey et al. 1982 a; Barbey 1982; Barbey et al. to be published), only their main features are summarized in the next two paragraphs.

\section{The khondalite suite}

This suite has an overall sedimentary parentage (Table 3 ) and is characterized by the recurrent alternation of sillimanite-garnet gneisses (metashales) and various garnet gneisses that, according to the prevailing feldspar and in de- 


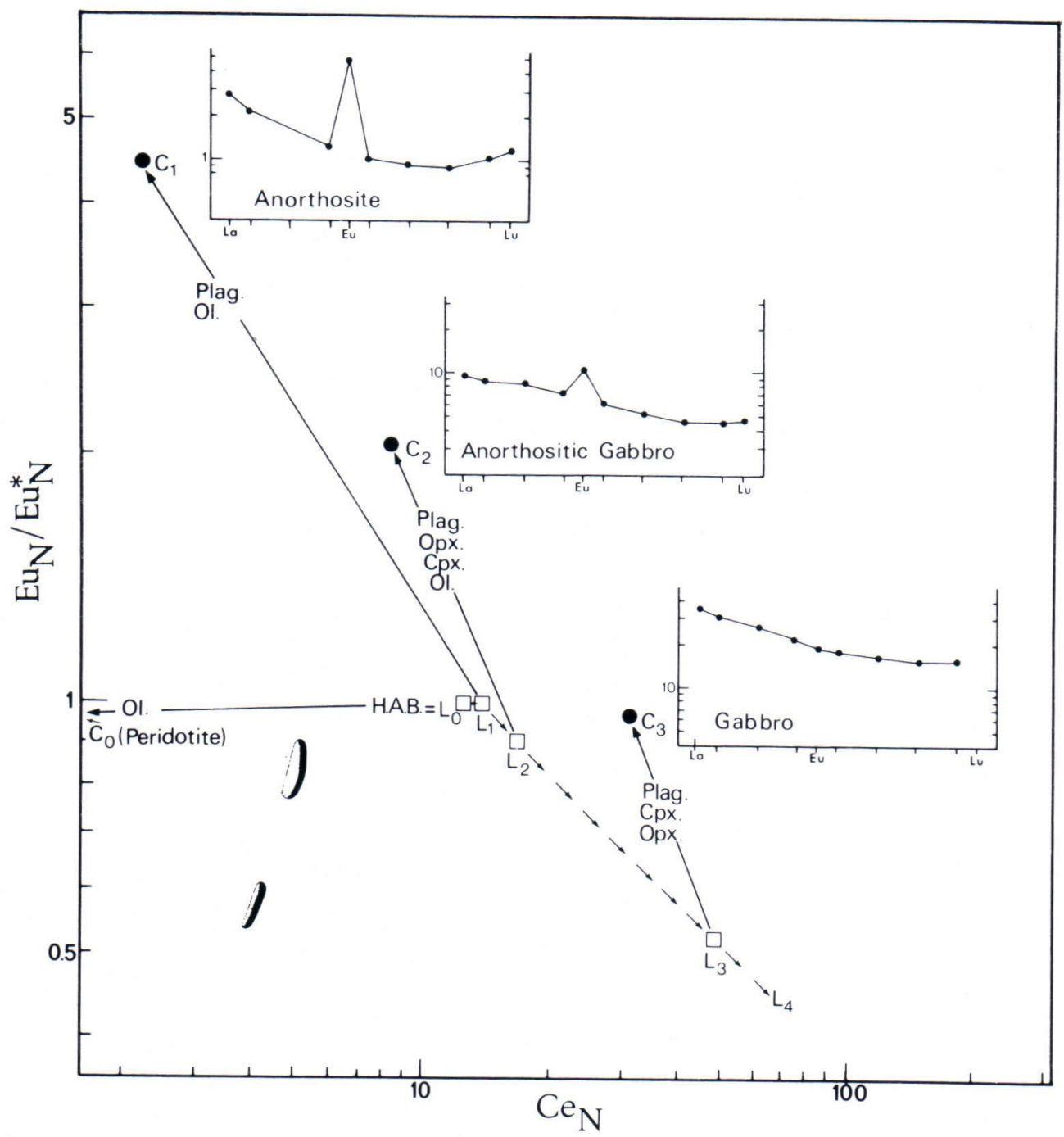

Fig. 4. Model interpretation of the evolution of the Vaskojoki anorthositic complex from the fractional crystallization of a high-alumina basalt parental magma. Data from Moreau (1980, 1981). The partition coefficients for basaltic liquids are from Arth and Hanson (1975) and the high-alumina basalt from Masuda (1968). (C = cumulate; L = liquid).

creasing order of abundance, are: a widespread perthite-bearing type (psammitic metagreywackes), several plagioclase-bearing types (volcanogenic metagreywackes and intermediate volcanics) and a rather scarce alkali-feldsparrich type (felsic volcaniclastics). These are interlayered with subordinate quartz-rich gneisses (metasandstones) and calc-silicate rocks (calcareous metasiltstones). Mixing calculations carried out by least-square regression analyses of all the pairs of major elements combined with computation of chemical modal compositions involving standard mineral analyses (see Barbey et al. 1982 a) permitted a model of the sedimentary precursors and their depositional environment to be established.

On account of the very close correlations between $\mathrm{SiO}_{2}, \mathrm{Al}_{2} \mathrm{O}_{3}, \mathrm{Fe}_{2} \mathrm{O}_{3}, \mathrm{MgO}, \mathrm{K}_{2} \mathrm{O}$ and 
$\mathrm{TiO}_{2}$, metashales can be likened to a mixture of quartz and clay minerals that corresponded originally to a fine-grained well sorted sediment. The mixing lines involving silica and alkalies and the computed modal compositions yield evidence of two sub-groups: one consisting of quartz and clay minerals only (mainly chlorite, illite plus minor kaolinite and/or montmorillonite), the other containing K-feldspar in addition to quartz, chlorite and illite and forming a transition with greywackes (Fig. 5). Psammitic metagreywackes extend the evolutionary trends of the metashales. In particular, regression lines between $\mathrm{Fe}_{2} \mathrm{O}_{3}, \mathrm{MgO}, \mathrm{Al}_{2} \mathrm{O}_{3}, \mathrm{TiO}_{2}$ and $\mathrm{SiO}_{2}$ display the same slopes and intercepts as in metashales, but with poorer correlations (Fig. 6). This implies that the same mineral assemblage was maintained in these metagreywackes and suggests that they were equivalent to a mixture between shales and an additional poorly sorted arenaceous fraction. Distinct residual igneous features reflecting the diversity of the source area have been observed: either granitic (higher $\mathrm{K}$ content and a normative plagioclase $\mathrm{An} \leqslant 25$ ) or granodioritic to dioritic (lower K content and a normative plagioclase $25 \leqslant$ An $\leqslant 35$ ). Although intimately associated with the former types, volcanogenic metagreywackes constitute a separate group with strong igneous characteristics (replacement of plagioclase by $\mathrm{K}$-feldspar and an increase in the $\mathrm{Na} / \mathrm{Ca}$ ratio with increasing silica, transition trace element patterns). Nevertheless, their excess alumina content shows that they contained clayey matrix in significant amounts. All these features suggest that the rocks corresponded to lithic greywackes derived either from reworked volcaniclastic material or from the erosion of a weakly weathered granodioritic continental crust.

Table 3. Average major and trace element compositions of the main lithological types of the khondalite suite. Major elements on an anhydrous basis. Standard deviation in brackets. Compiled from Barbey 1982; Barbey et al. 1982 a; Barbey and Cuney 1982. (a, b, c, based respectively on 1, 2, 3 samples only).

\begin{tabular}{|c|c|c|c|c|c|}
\hline & Metashales & $\begin{array}{c}\text { Psammitic } \\
\text { metagraywackes }\end{array}$ & $\begin{array}{l}\text { Volcanogenic } \\
\text { metagraywackes }\end{array}$ & Metasandstones & $\begin{array}{l}\text { Calcareous } \\
\text { metasiltstones }\end{array}$ \\
\hline $\mathrm{n}$ & 27 & 30 & 12 & 9 & 9 \\
\hline $\mathrm{SiO}_{2}$ & $62.22(5.7)$ & $76.06(2.8)$ & $68.58(2.9)$ & $84.70(2.3)$ & $75.22(7.6)$ \\
\hline $\mathrm{Al}_{2} \mathrm{O}_{3}$ & $19.03(3.2)$ & $11.72(1.5)$ & $15.75(0.6)$ & 7.59 (1.6) & $10.95(3.7)$ \\
\hline $\mathrm{Fe}_{2} \mathrm{O}_{3}$ & $8.84(1.9)$ & $4.68(0.9)$ & $4.84(2.3)$ & $2.79(0.4)$ & $3.07(0.7)$ \\
\hline $\mathrm{MnO}$ & $0.12(0.04)$ & $0.06(0.04)$ & $0.08(0.06)$ & $0.04(0.01)$ & $0.11(0.05)$ \\
\hline $\mathrm{MgO}$ & $3.17(0.7)$ & $1.57(0.4)$ & $1.82(0.8)$ & $0.73(0.2)$ & $1.44(0.7)$ \\
\hline $\mathrm{CaO}$ & $0.69(0.2)$ & $1.00(0.4)$ & $2.47(0.9)$ & $1.36(0.7)$ & $7.81(3.6)$ \\
\hline $\mathrm{Na}_{2} \mathrm{O}$ & $1.27(0.4)$ & $1.69(0.4)$ & $2.83(0.4)$ & $1.55(0.5)$ & $0.45(0.2)$ \\
\hline $\mathrm{K}_{2} \mathrm{O}$ & $3.83(0.9)$ & $2.71(0.8)$ & $3.02(1.5)$ & $0.86(0.3)$ & $0.57(0.4)$ \\
\hline $\mathrm{TiO}_{2}$ & $0.84(0.2)$ & $0.53(0.1)$ & $0.58(0.4)$ & $0.39(0.1)$ & $0.38(0.1)$ \\
\hline $\mathrm{n}$ & 11 & 14 & 8 & 3 & 2 \\
\hline $\mathrm{Rb}$ & $110(15)$ & $69(25)$ & 84 (32) & $27(19)$ & 18 (19) \\
\hline $\mathrm{Sr}$ & $211(50)$ & $206(42)$ & 352 (107) & 175 (105) & $182(26)$ \\
\hline $\mathrm{Ba}$ & $985(166)^{b}$ & $877(326)^{b}$ & $896(478)^{c}$ & $314^{a}$ & \\
\hline $\mathrm{Zr}$ & $203(31)$ & 219 & 198 & 303 (113) & $185(21)$ \\
\hline Y & $39(7)$ & $28(3)$ & $26(11)$ & $15(7)$ & $22(6)$ \\
\hline $\mathrm{Nb}$ & $17(4)$ & $14(13)$ & $<10$ & $<10$ & $<10$ \\
\hline $\mathrm{Ni}$ & $34(19)$ & $25(14)$ & 37 (12) & $<10$ & $20(13)$ \\
\hline Co & $15(4)$ & $11(2)$ & $11(4)$ & $<10$ & $<10$ \\
\hline V & $125(34)$ & $75(247$ & $72(40)$ & $45(9)$ & $28(4)$ \\
\hline $\mathrm{Cr}$ & $130(37)$ & $82(31)$ & $53(41)$ & $50(5)$ & $41(4)$ \\
\hline U & $0.9(0.5)$ & $0.6(0.3)$ & $0.6(0.3)$ & $1.2(0.8)$ & $2.1(0.7)^{c}$ \\
\hline Th & $14.8(4)$ & $9.4(4.6)$ & $11.1(6.8)$ & $14.8(8.9)$ & $11.6(2.8)$ \\
\hline
\end{tabular}




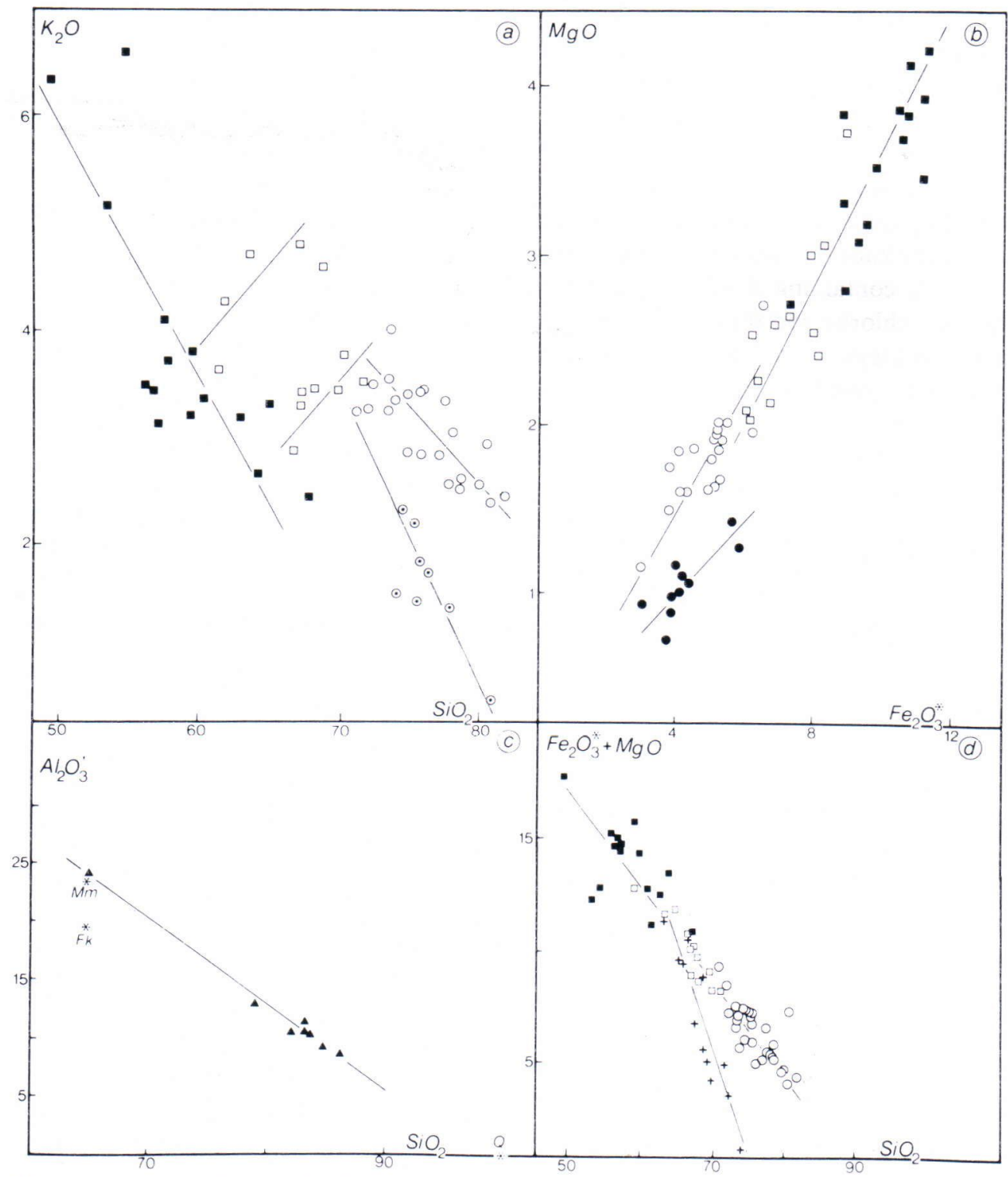

Fig. 5. Distinctive variation diagrams for the main lithological groups of the khondalite suite (Granulite belt). Solid lines are least-square regression lines.

a) $\mathrm{K}_{2} \mathrm{O}-\mathrm{SiO}_{2}$ diagram for metashales (sillimanite-garnet gneisses) and psammitic metagreywackes (K-feldspar-rich garnet gneisses). Each group displays two different trends: Metashales correspond to mixtures of quartz + clay minerals (solid squares) or of quartz + clay minerals + detrital K-feldspar (open squares), and psammitic metagreywackes display either granitic (open circles) or granodioritic to dioritic (dotted circles) residual igneous features. Partly redrawn from Barbey et al. (1982 a).

b) Plot of $\mathrm{MgO}$ vs. $\mathrm{Fe}_{2} \mathrm{O}_{3}{ }^{*}$ for metashales (squares) and psammitic metagreywackes (circles). The two subgroups of metagreywackes are different from those of the former diagram.

c) $\mathrm{Al}_{2} \mathrm{O}_{3}{ }^{\prime}-\mathrm{SiO}_{2}$ ' diagram for calcareous metasiltstones (calc-silicate rocks). $\mathrm{Al}_{2} \mathrm{O}_{3}$, and $\mathrm{SiO}_{2}$ ' values are oxide weight percentages recalculated for $\mathrm{CaO}=\mathrm{O}$. Standard analyses of minerals have also been indicated $(\mathrm{Mm}=$ Montmorillonite; $\mathrm{Fk}=\mathrm{K}$-feldspar; $\mathrm{Q}=$ Quartz).

d) $\left(\mathrm{Fe}_{2} \mathrm{O}_{3}{ }^{*}+\mathrm{MgO}\right)$ vs. $\mathrm{SiO}_{2}$ plot showing the distinct features of the volcanogenic metagreywackes (plagioclasegarnet gneisses) (crosses) with respect to metashales (squares) and psammitic metagreywackes (circles). From Barbey et al. 

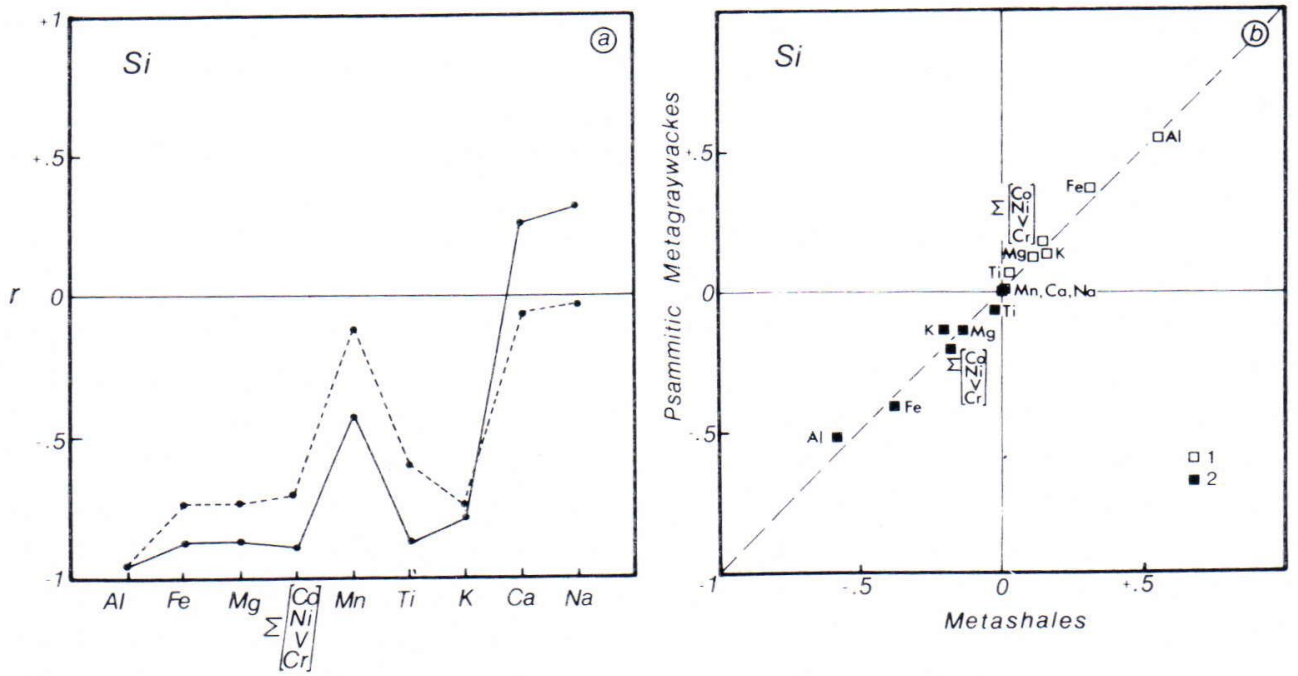

Fig. 6. Diagrams summarizing the variations in $\mathrm{Al}, \mathrm{Fe}, \mathrm{Mg}, \mathrm{Mn}, \mathrm{Ti}, \mathrm{K}, \mathrm{Ca}, \mathrm{Na}$ and the sum $(\mathrm{Co}, \mathrm{Ni}, \mathrm{V}, \mathrm{Cr})$ against $\mathrm{Si}$ (oxide weight percentages) and showing the close identity of the chemical trends (mixing lines) between metashales and psammitic metagreywackes. line).

a) Correlation coefficient patterns of metashales (solid line) compared with those of psammitic metagreywackes (dotted

b) Comparison of intercept (1) and slope (2) values between metashales (x-axis) and psammitic metagreywackes (y-axis) (slope values $<0$; intercept values $>0$ and $\times 10^{-2}$ ).

Calcareous metasiltstones are composed mainly of $\mathrm{SiO}_{2}, \mathrm{Al}_{2} \mathrm{O}_{3}$ and $\mathrm{CaO}$ with a typical low alkali content probably related to sedimentary processes (Barbey 1982). Their general characteristics are those of silty-sized sediments and are due to the dilution of a quartz-clay mineral mixture (apparently montmorillonite) by a carbonate matrix (calcite and siderite/ankerite). $\mathrm{Sr}, \mathrm{Zr}$, Th and $\mathrm{U}$ abundances corroborate the importance of the argillaceous fraction and preclude the presence of both detrital plagioclase and chemical Ca sulphates.

The remarkable equivalence of the chemical patterns between metashales and psammitic metagreywackes, implying identical mineral assemblages and contrasting with the variable correlations (close for metashales, poorer for metagreywackes), and their monotonous alternation suggest that these two groups represent two fractions of different size of the same initial detrital material. Such a vertical sedimentary succession of both arenaceous and lutaceous beds displays typical features of a turbidite formation. Unfortunately we lack reliable data permitting us to know whether these are true deep-sea fan sediments or were deposited in a rather deep shelf-sea. The only argument provided by the geological context is that shallowwater sediments are still represented on both sides of the basin by the epicontinental Jatulian formations (see later). The geochemical trends of alkalies are similar to those for the Lower Proterozoic (Engel et al. 1974) and reflect the fractionated nature of the continental source area. The markedly low $\mathrm{CaO}$ content of this sequence implies that there was no $\mathrm{Ca}$ carbonate precipitation and suggests that intense weathering of the source continent destroyed plagioclases. These observations are consistent with the absence of Ca carbonate deposition in open milieux before the Upper Silurian (Veizer 1973) and are corroborated by the widespread distribution of continental weathering crusts at the base of the Jatulian formations (see Silvennoi- 
nen, 1980). Despite their strong igneous features, volcanogenic metagreywackes are part of the former terrigenous sequence. Three possible sources might have contributed to the formation of these lithic greywackes: deep recurring erosion of an Archean continental crust (instability of the margin, climatic changes, etc.) and/or reworked volcanics originating in the Archean greenstone belts or arising from a contemporaneous volcanic activity. The presence of carbonate beds in this thick terrigenous sequence accumulated near the rise of a continent is inconsistent with the depositional environment of carbonate sediments in the Precambrian, which was restricted to littoral or semibarred sequences (Veizer 1973). Although this means that these two sedimentary facies were formed in widely separated environments, the carbonate sediments could have been brought together with shales and greywackes from a nearby shallow-water platform by turbidity currents.

These data suggest that the khondalite suite resembles a flysch-type series and corresponds to a flysch-belt of mass-flow and turbidite deposits.

The relatively small volume of volcanic detritus and their unreliable origin (the combined result of several sources) are not easily reconciled with an island-arc type environment (Raith et al. 1982). Further, because of the apparent maturity of these sediments (especially the absence of conglomeratic piedmont formations), they are quite different from synorogenic flysch sediments (Andean type) but rather close to Atlantictype sediments, keeping in mind that sedimentary facies like this occur in early stages of geosynclines.

Table 4. Average compositions of the two tholeiitic series of the charnockitic complex. Standard deviation in brackets. Compilation from Barbey, 1982; Barbey and Cuney 1982. 1) $\mathrm{SiO}_{2} \leqslant 52 \%$; 2) $56 \leqslant \mathrm{SiO}_{2} \leqslant 61 \%$; 3 ) $\mathrm{SiO}_{2}>61 \%$. (a, b, c, d, based respectively on 1, 2, 3, 4, samples only).

\begin{tabular}{|c|c|c|c|c|c|c|}
\hline & \multicolumn{3}{|c|}{$\mathrm{TH}-1$ series } & \multicolumn{3}{|c|}{$\mathrm{TH}-2$ series } \\
\hline & 1 & 2 & 3 & 1 & 2 & 3 \\
\hline $\mathrm{n}$ & 5 & 2 & 3 & 3 & 3 & 3 \\
\hline $\mathrm{SiO}_{2}$ & $49.29(2.5)$ & $57.83(0.6)$ & $62.29(1.8)$ & $50.67(0.3)$ & $53.78(1.4)$ & $57.52(0.7)$ \\
\hline $\mathrm{Al}_{2} \mathrm{O}_{3}$ & $18.78(2.2)$ & $16.96(0.5)$ & $16.16(0.5)$ & $18.55(0.5)$ & $18.43(1.2)$ & $17.60(0.6)$ \\
\hline $\mathrm{Fe}_{2} \mathrm{O}_{3}$ & $9.83(1.4)$ & $10.51(0.05)$ & $8.47(0.8)$ & $10.29(0.6)$ & $9.93(1.4)$ & $8.45(0.6)$ \\
\hline $\mathrm{MnO}$ & $0.12(0.03)$ & $0.10(0.04)$ & $0.12(0.05)$ & $0.14(0.01)$ & $0.11(0.02)$ & $0.09(0.01)$ \\
\hline $\mathrm{MgO}$ & $5.72(1.3)$ & $3.17(0.01)$ & $2.29(0.6)$ & $5.72(0.5)$ & $5.02(1.1)$ & $3.75(0.4)$ \\
\hline $\mathrm{CaO}$ & $8.55(2.3)$ & $6.03(0.8)$ & $3.83(1.0)$ & $8.12(0.4)$ & $6.90(0.8)$ & $6.10(0.2)$ \\
\hline $\mathrm{Na}_{2} \mathrm{O}$ & $2.44(0.7)$ & $2.33(1.4)$ & $2.84(0.1)$ & $3.19(0.7)$ & $2.97(0.7)$ & $3.29(0.3)$ \\
\hline $\mathrm{K}_{2} \mathrm{O}$ & $1.81(0.9)$ & $1.12(0.01)$ & $1.66(0.5)$ & $0.56(0.2)$ & $0.97(0.5)$ & $0.82(0.09)$ \\
\hline $\mathrm{TiO}_{2}$ & $1.02(0.3)$ & $1.52(0.1)$ & $0.94(0.2)$ & $1.42(0.6)$ & $1.05(0.07)$ & $1.09(0.1)$ \\
\hline $\mathrm{P}_{2} \mathrm{O}_{5}$ & $0.60(0.5)$ & $0.30(0.07)$ & $0.29^{\mathrm{a}}$ & $0.42(0.2)$ & $0.27(0.07)$ & $0.22(0.03)$ \\
\hline $\mathrm{n}$ & 5 & 2 & 3 & 3 & 3 & 3 \\
\hline $\mathrm{Rb}$ & $67(55)$ & 33 (29) & $51(28)$ & 7 (4) & $21(20)$ & $7(1)$ \\
\hline $\mathrm{Sr}$ & $750(630)$ & 404 (60) & $245(66)$ & $657(102)$ & 570 (167) & $470(260)$ \\
\hline $\mathrm{Ba}$ & $877(278)^{b}$ & & & & $524(203)$ & $436(70)$ \\
\hline $\mathrm{Zr}$ & $161(92)$ & $212(67)$ & $201(84)$ & $112(34)$ & $119(47)$ & $109(65)$ \\
\hline Y & $27(3)$ & $29(4)$ & 40 (11) & $16(3)$ & $14(3)$ & $7(1)$ \\
\hline $\mathrm{Nb}$ & $11(10)$ & $14(6)$ & $11(1)$ & $<10$ & $<10$ & $<10$ \\
\hline $\mathrm{Ni}$ & $40(17)^{c}$ & $33(0)$ & & $46(14)^{b}$ & $45(23)^{b}$ & $49(8)$ \\
\hline Co & $45(24)^{d}$ & 52 (11) & $28(5)^{\mathrm{b}}$ & $48(1)^{\mathrm{b}}$ & 52 (13) & 76 (23) \\
\hline V & $196(47)^{d}$ & $166(48)$ & $135(22)^{b}$ & $220(4)^{b}$ & 203 (54) & $162(11)$ \\
\hline $\mathrm{Cr}$ & $65(21)^{c}$ & $48(9)$ & $104(13)^{b}$ & $92(21)^{b}$ & $114(86)$ & 81 (19) \\
\hline
\end{tabular}




\section{The charnockitic complex}

Except for some minor ultramafic varieties, the complex is composed of typically plagioclase and pyroxene-bearing meta-igneous rocks corresponding to norites, enderbites and charnoenderbites. The diversity of their occurrence reflecting their variable origin (small foliae to thick intercalations in metasediments conformable with the regional structures and crosscutting bodies displaying relict igneous textures) and the evidence of the existence of residual magmatic pyrope-rich almandine garnets in some synmetamorphic intrusions indicate: (1) the probable presence of volcanic layers interbedded with metasediments (2) the syngranulitic emplacement of some intrusions (characterized by garnet fractionation, and subsequently (3) the persistence of magmatic activity throughout the evolution of the mobile belt.

Major and trace element geochemistry shows the great complexity of this unit with its several fractionated igneous suites (Fig. 7) of tholeiitic and calc-alkaline affinity (Barbey 1982; Barbey et al. to be published).

The tholeitic series range in composition from basalts (which can be defined as low-K tholeiites) to andesites (Table 4) and are characterized by a moderate increase in $\mathrm{TiO}_{2}$ at the first stages of the differentiation (Fig. 7 b). The twofold field relationships between charnockitic rocks and metasedimentary granulites (conformable layers and crosscutting bodies) and the development of an earlier tholeiitic volcanism in the Tana belt indicate the probable existence of both effusive and intrusive tholeitic rocks in the Granulite belt. On account of the increase in the $\mathrm{Y}$ content with progressive differentiation in the tholeiitic series of the Tana belt as opposed to the evidence of garnet fractionation in the syngranulitic intrusions, the calcium-yttrium relationships (Lambert and Holland 1974) constitute a reliable way of separating the possible volcanics (and early intrusives) from later synmetamorphic plutonics.
The trend of the first series (Fig. $7 \mathrm{~d}$ ) corresponds to an increase in the $\mathrm{Y}$ content as $\mathrm{CaO}$ decreases and is probably caused mainly by clinopyroxene-plagioclase fractionation. This series includes samples interpreted as metavolcanics on the basis of field data. The trend of the second series is drawn by a gradual impoverishment in $\mathrm{Y}$ with decreasing lime content. This contrasting behaviour can be attributed to garnet fractionation in addition to plagioclase and clinopyroxene at some stage of the differentiation. This interpretation is supported by the following arguments: (1) the garnet stability field was reached during peak metamorphic conditions by rocks with an $\mathrm{X}_{\mathrm{Mg}}$ lower than 0.5 (as in these tholeiitic rocks), ((2) hornblende, whose structure can also readily accommodate $\mathrm{Y}$, was probably not stable owing to the high $\mathrm{CO}_{2}$ partial pressure prevailing during the metamorphism (see later), (3) the poorer iron enrichment in the second series with respect to magnesia and alkalies is consistent with the fractionation of a pyrope-rich almadine.

These two series can apparently also be distinguished by their $\mathrm{K}, \mathrm{Rb}$ and Ba geochemistry (Fig. $7 \mathrm{f}$ ). The first series (metavolcanics and early intrusives) displays low $\mathrm{K} / \mathrm{Rb}$ ratios (200-400) similar to those of the khondalite suite, whereas the second (syngranulitic metaplutonics) has higher ratios ranging from those of the first series $(\mathrm{K} / \mathrm{Rb} \leqslant 400)$ to those of the island arc (Jakes and White 1980) or oceanic (Shaw 1968) tholeiites $(K / R b \geqslant 1000)$. This has been interpreted by differential re-equilibration of the two series with the surrounding metasediments, depending on the composition of the metamorphic fluid (see Barbey and Cuney 1982 for further details). Their REE distribution patterns and isotopic constitution (BernardGriffiths et al. 1984; Barbey et al. to be published) suggest that they could be due to the fractional crystallization of two identical magmas.

Three calc-alkaline series composed of basaltic and andesitic members (Table 5), have been distinguished (Fig. 7 a). The Fe, Ti, V, Zr, Y and 


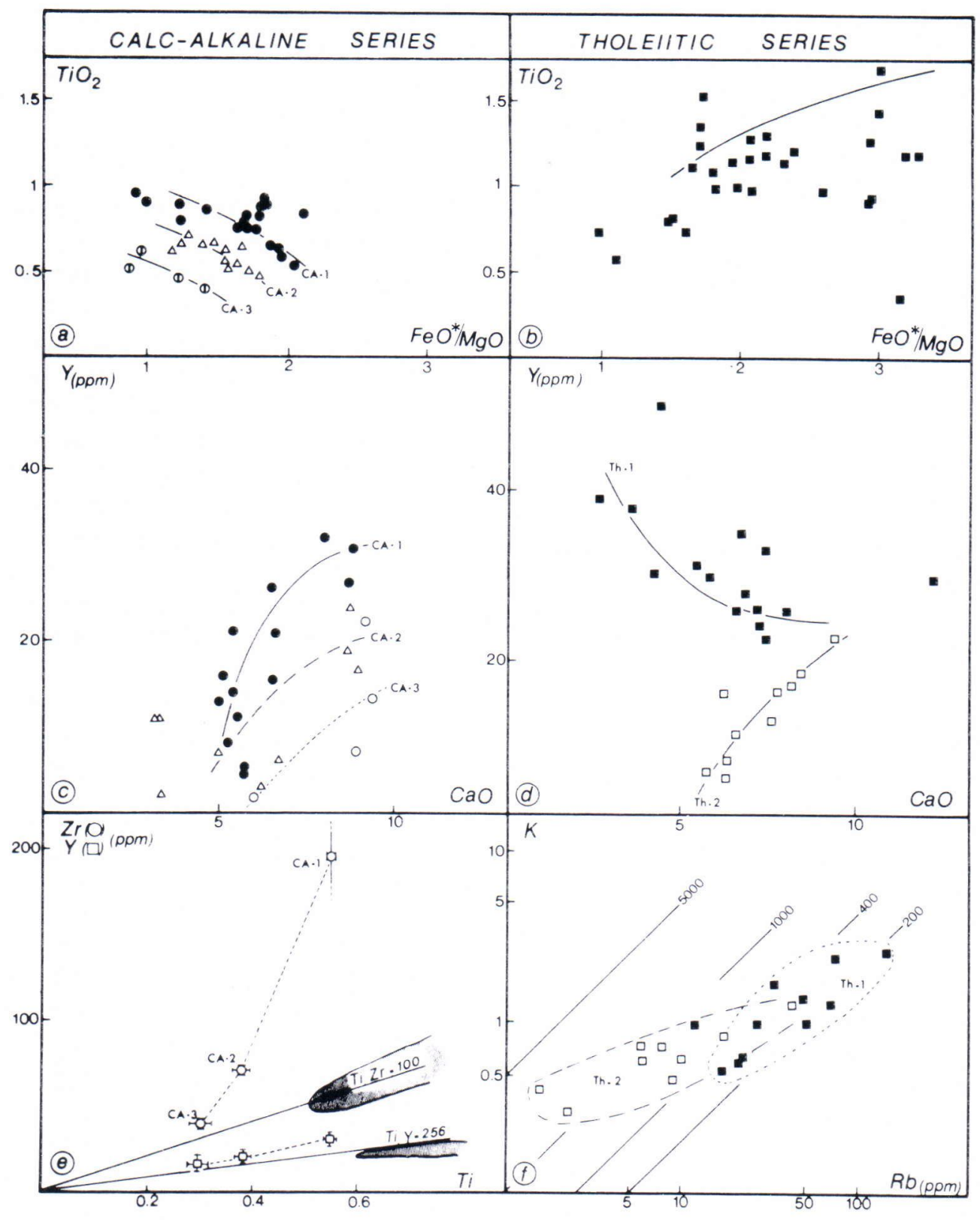

Fig. 7. Distinctive variation diagrams of the calc-alkaline and tholeiitic series of the charnockitic complex.

Analytical data and diagrams (a), (b), (c) and (d) from Barbey et al. (to be published).

Diagram (e) - The $\mathrm{Ti} / \mathrm{Zr}$ and $\mathrm{Ti} / \mathrm{Y}$ chondritic values and the MORB field (shaded areas) are from Nesbitt and Sun (1976). Symbols correspond to the average $\mathrm{Zr}, \mathrm{Y}$ and Ti contents of the basaltic compositions (two-sigma values given between brackets).

Diagram (f) - Redrawn from Barbey and Cuney (1982). 
REE contents decrease as differentiation increases and proceed in decreasing order of abundance from the basaltic terms of the $\mathrm{CA}-1$ series to those of the $\mathrm{CA}-3$ series. Allowing for their Y behaviour, which is similar to that of the second tholeiitic series (Fig. $7 \mathrm{c}$ ), these calcalkaline suites may correspond to syngranulitic plutonics.

The main features of all the magmatic series constituting the charnockitic complex raise the following points.

(1) The succession of several tholeiitic magmatic episodes (effusive and intrusive) in both the Tana and Granulite belts, makes it difficult to establish whether these recurring tholeiitic injections are parts of a single time-transgressive magmatic activity or whether they are related to two distinct events. All these igneous suites display very similar chemical features, and we believe these volcanic and plutonic series are different expressions of the same major diachronous magmaforming event: initially, volcanism and low pressure magma differentiation during the geosynclinal stage and, later, plutonism associated with higher pressure magma differentiation during the collisional event.

(2) The parallelism between the evolutionary trends of the three calc-alkaline series and their respective incompatible element contents are inconsistent with their differentiation from a single primary liquid. On the other hand, major and trace element variations, in particular the mean $\mathrm{Ti} / \mathrm{Zr}$ and $\mathrm{Ti} / \mathrm{Y}$ ratios and the REE patterns of the basaltic compositions from one series to another (Fig. 7 e), suggest that they originated through the fractional crystallization of three distinct liquids that arose from different melting rates (increasing from the $\mathrm{CA}-1$ to the $\mathrm{CA}-3$ series) of the same chondritic source. $\mathrm{Rb}-\mathrm{Sr}$, $\mathrm{Sm}-\mathrm{Nd}$ and $\mathrm{Pb}-\mathrm{Pb}$ systematics are compatible

Table 5. Average composition of the three calc-alkaline series of the charnockitic complex. Standard deviation in brackets. 1) $\mathrm{SiO}_{2} 52 \%$; 2) $56 \% \mathrm{SiO}_{2} 61 \%$; 3) $\mathrm{SiO}_{2} 61 \%$. (a, b, c, d, based respectively on 1, 2, 3, 4, samples only; (o) = analysis from Raith et al. 1982).

\begin{tabular}{|c|c|c|c|c|c|c|c|c|}
\hline & \multicolumn{3}{|c|}{$\mathrm{CA}-1$ series } & \multicolumn{3}{|c|}{$\mathrm{CA}-2$ series } & \multicolumn{2}{|c|}{$\mathrm{CA}-3$ series } \\
\hline & 1 & 2 & 3 & 1 & 2 & 3 & 1 & $2^{(\circ)}$ \\
\hline $\mathrm{n}$ & 3 & 10 & 6 & 3 & 4 & 4 & 1 & 1 \\
\hline $\mathrm{SiO}_{2}$ & $49.87(0.4)$ & $59.01(1.9)$ & $62.06(0.8)$ & $51.33(0.8)$ & $58.85(1.3)$ & 62.91 (1.6) & 50.62 & 59.23 \\
\hline $\mathrm{Al}_{2} \mathrm{O}_{3}$ & $14.37(1.9)$ & $17.70(0.1)$ & $17.10(0.9)$ & $18.43(0.4)$ & $18.40(1.1)$ & $17.20(1.0)$ & 18.66 & 19.29 \\
\hline $\mathrm{Fe}_{2} \mathrm{O}_{3}$ & $9.94(1.2)$ & $6.23(0.9)$ & $5.73(0.5)$ & $7.90(0.06)$ & 6) $5.94(0.3)$ & $4.95(0.2)$ & 8.32 & 5.99 \\
\hline $\mathrm{MnO}$ & $0.15(0.02)$ & $0.09(0.02)$ & $0.09(0.02)$ & $0.12(0.02)$ & $0.07(0.02)$ & $0.13(0.13)$ & 0.13 & 0.08 \\
\hline $\mathrm{MgO}$ & $9.67(1.6)$ & $3.52(0.7)$ & $3.04(0.5)$ & $6.23(0.6)$ & $3.54(0.2)$ & $3.20(0.2)$ & 9.15 & 3.92 \\
\hline $\mathrm{CaO}$ & $8.47(0.4)$ & $5.81(0.5)$ & $5.02(0.6)$ & $8.80(0.2)$ & $5.80(0.9)$ & $4.85(0.6)$ & 9.38 & 5.95 \\
\hline $\mathrm{Na}_{2} \mathrm{O}$ & $2.64(0.1)$ & $3.41(0.5)$ & $3.08(0.4)$ & $2.58(0.4)$ & $3.20(0.2)$ & $3.36(0.1)$ & 1.56 & 3.36 \\
\hline $\mathrm{K}_{2} \mathrm{O}$ & $1.46(0.9)$ & $1.59(0.5)$ & $1.86(0.9)$ & $0.92(0.3)$ & $1.26(0.3)$ & $1.53(0.6)$ & 0.40 & 0.94 \\
\hline $\mathrm{TiO}_{2}$ & $0.91(0.02)$ & $0.77(0.1)$ & $0.71(0.2)$ & $0.63(0.03)$ & $0.58(0.08)$ & $0.59(0.07)$ & 0.46 & 0.39 \\
\hline $\mathrm{P}_{2} \mathrm{O}_{5}$ & $0.59(0.2)$ & $0.30(0.1)$ & $0.15(0.05)$ & $0.70(0.7)$ & $0.26(0.1)$ & $0.22(0.02)$ & 0.25 & 0.13 \\
\hline $\mathrm{n}$ & 3 & 9 & 3 & 3 & 3 & 3 & 1 & 1 \\
\hline $\mathrm{Rb}$ & $40(31)$ & $40(20)$ & $45(6)$ & $9(2)^{\mathrm{b}}$ & $33(11)$ & $35(22)$ & 3 & 42 \\
\hline $\mathrm{Sr}$ & $729(198)^{b}$ & $538(166)$ & 449 (54) & $564(4)^{b}$ & $536(52)$ & $501 \quad(52)$ & 420 & 313 \\
\hline $\mathrm{Ba}$ & 1221 & $590(161)^{c}$ & $485(121)$ & $327^{a}$ & 361 (113) & 667 (143) & 127 & 475 \\
\hline $\mathrm{Zr}$ & $197(168)$ & $116(45)$ & 107 (11) & $125(93)$ & 77 (43) & $138(38)$ & 39 & \\
\hline Y & $30(3)$ & $14(8)$ & $24(19)$ & $20(4)$ & $7(4)$ & $7(5)$ & 13 & 1 \\
\hline $\mathrm{Nb}$ & $<10$ & $<10$ & $<10$ & $<10$ & $<10$ & $<10$ & $<10$ & \\
\hline $\mathrm{Ni}$ & $158(20)^{\mathrm{b}}$ & $54(17)^{\mathrm{c}}$ & & $53(11)^{b}$ & & & 97 & 42 \\
\hline $\mathrm{Co}$ & $59(4)^{\mathrm{b}}$ & $27(16)^{d}$ & $14(1)$ & $37(12)^{b}$ & $30(18)$ & & 72 & \\
\hline V & $223(37)^{b}$ & $119(22)^{\mathrm{d}}$ & $97(11)^{b}$ & $167(43)^{b}$ & $112(21)$ & & 147 & 68 \\
\hline $\mathrm{Cr}$ & $587(417)$ & $96(39)^{c}$ & & $318(11)^{\mathrm{b}}$ & & & 391 & 109 \\
\hline
\end{tabular}


with a single source of mantle origin or with a multistage process involving rocks of short crustal residence time (Bernard-Griffiths et al. 1984). Nevertheless, the $\mathrm{Ti} / \mathrm{Zr}$ and $\mathrm{Ti} / \mathrm{Y}$ ratios in the basaltic terms of the third series (CA-3), corresponding to the highest degree of melting in the above interpretation, preclude their derivation from MORB-type basalts (Fig. 7 e) in a conventional subduction model.

\section{The Archean cratons}

The Inari-Kola craton to the northeast and the South Lapland-Karelia craton to the southwest form two Archean provinces whose chemical patterns imply that they represent the continental crust source of the metasediments of the Granulite belt (Barbey et al. 1982 a). These two domains suffered intense deformation and recrystallization during the Belomorian mobile belt-forming event and have subsequently acquired a polycyclical aspect.

The Inari-Kola craton corresponds to a deeply eroded section of grey gneisses and greenstones of which the oldest known age is $2.86 \mathrm{Ga}$ (Meriläinen 1976). This continental domain was substantially reworked during the development of the Belomorides, leading to complex deformational patterns, intense remobilization and to a complete $\mathrm{Rb}-\mathrm{Sr}$ isotopic rehomogenization as one approaches the Granulite belt (Martin, unpubl. result). Moreover, a number of plutons (either foliated or undeformed) of early Proterozoic age (Meriläinen 1976), ranging from gabbro to granite but mostly dioritic to granodioritic, intrude the older basement. This intense calc-alkaline plutonism is typically lacking in the opposite craton, a feature that accentuates the assymetry of the mobile belt and recalls Cordilleran plutonism.

The South Lapland-Karelia craton displays two very different aspects. In Lapland, it corresponds to an assemblage of gneiss domes fringed by low-grade greenstone synforms (Kit- tilä, Jauratsi and Tuntsa-Savukoski belts). The basement gneisses are as old as $3.10 \mathrm{Ga}$ (Kröner et al. 1981). In Karelia and along the White Sea shores in the USSR, the Archean gneisses have been penetratively refoliated and recrystallized from lower to upper amphibolite grade. Locally, they were overthrusted onto the Jatulian formations (Kratz 1978) during the Karelian event, $1.9-2.0 \mathrm{Ga}$ ago.

\section{The Jatulian and Svecofennian formations}

A suitable evolutionary model of the Belomorian fold belt could not be established without taking into account the volcanosedimentary Jatulian formations that were deposited contemporaneously, as demonstrated by recent radiometric dating of Lapland granulites (BernardGriffiths et al. 1984). The nature and distribution of the Jatulian sediments also provide interesting indications regarding the structure of the early Proterozoic continental crust close to the Belomorian geosyncline. At the same time it might be advisable to reconsider the relationships between the Belomorides and the Svecofennides.

\section{The Jatulian}

The data summarized here are taken from the Symposium on Jatulian Geology (Silvennoinen 1980), to which the reader is referred for further details.

The Jatulian formations of the Kola Peninsula are restricted to a narrow belt running along the Belomorides (Fig. 8) that is known as the Pechenga - Varzuga rift (Zagorodnyi 1980) or the Petsamo Group (Oftedahl 1980) and which probably includes the Apukasjärvi schist zone (Meriläinen 1976). According to Zagorodnyi, the Lower Jatulian (Umba and Kuetsjärvi formations) comprise continental to epicontinental sediments (chemical weathering crusts, sandstones, dolomitic sandstones and dolo- 
Fig. 8. Geological sketch map of the Belomorian geotectonic assemblage. After Glebovitsky et al. (in Kratz 1978), Zhuravlev (1980), Ofedahl (1980), Barbey (1982), Gaàl (1982) and Krill (pers. comm., 1983). Continental crust of Karelia and Kola Peninsula: 1) undifferentiated basement (Archean and Proterozoic gneisses and granites), 4) Archean basement reactivated during the $1.9-2.0 \mathrm{Ga}$ orogenic event, 5a - Jatulian volcano-sedimentary cover, $5 \mathrm{~b}-$ Jatulian continental and paralic environments.

Belomorian geosyncline: 2) Tana belt, 3) Granulite belt. Svecofennian geosyncline (6) and Phanerozoic cover (7).

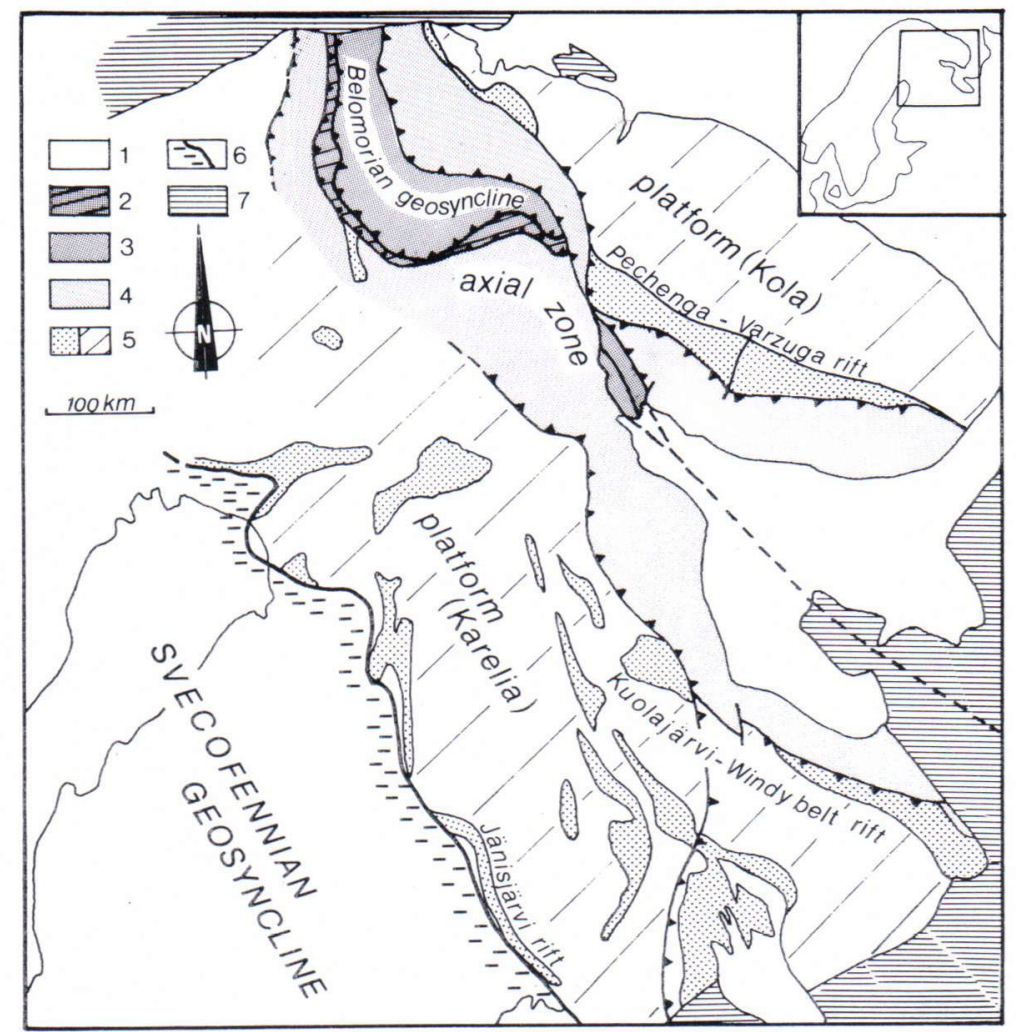

mites) overlain by alkaline tuffs and lavas (basalts, trachybasalts and trachyandesites, etc.). The next unconformable stratigraphic unit (Kolasjoki formation), likened to the Upper Jatulian, is represented by shallow-water sediments (arkoses grading into quartzites, sandstones and stromatolitic dolomites) capped by tholeiitic lava flows containing tuffogenic intercalations.

The Jatulian formations of Finnish and Soviet Karelia and of South Lapland (Fig. 8) were deposited on a continental platform and locally in fault-bounded troughs (Jaanisjärvi, Kuolajärvi, Windy beit). Stratigraphic equivalents have recently been recognized up to the Pokka area south of the Granulite belt (Barbey, 1982). Three volcanic episodes, mainly of tholeiitic affinity, mark the gradual change from a transitional (shoreline) to a marine (shelf) depositional environment. Continental weathering crusts associated with eluvial breccias and conglomerate and dated at $2.30 \mathrm{Ga}$ (Sakko, in Meriläinen 1980) constitute the base of the Jatulian strata. The Lower Jatulian comprises mainly conglomerates, sandstones and sandy schists overlain by basaltic lavas and tuffites. This first episode ended with a general uplift of the basin (Svetov 1980). The Middle Jatulian is characterized by renewed and intensified volcanic activity following a short period of sedimentation. The Upper Jatulian coincides with general subsidence of the basin and is represented by conglomerates and sandstones (locally banded iron formations) overlain by organogenic dolomites (stromatolites and oncolites) that have been dated at 2.05 Ga in the Peräpohja area (Perttunen 1980). The Upper Jatulian ended with a third volcanic basaltic episode.

The widespread distribution of continental 
sediments at the base of the Jatulian shows that the present-day eastern part of the Baltic Shield corresponded in the Late Archean to a peneplain subject to weathering and erosional processes. The overall transgressive nature of the Jatulian and the existence of strongly oriented, fault-bounded troughs support the concept of an unstable, gradually subsiding continental crust on both sides of the Belomorides, related to a phase of rifting. Moreover, because of the close parallelism between the Granulite belt and the Jatulian sedimentary basins and the fact that their maximum depth was achieved during the geosynclinal stage of the Belomorian mobile belt the Jatulian formations can be considered as the epicontinental equivalent of the Belomorian geosynclinal sequence (Granulite belt). The close connection between the Jatulian formations and the Belomorian geotectonic assemblage is further corroborated by post-depositional features, particularly the fact that the Jatulian formations of Karelia were deformed and overthrust by the Belomorides during the orogenic event at 1.9-2.0 Ga (Kratz 1978) and that their metamorphic grade increases towards the axial zone of the mobile belt.

\section{The Svecofennian}

The Svecofennian geosyncline is located west of the Ladoga-Raahe shear belt (Gaàl et al. 1978) (Fig. 8). Radiometric ages indicate that it is likely to have been filled at about 1.88-1.92 (Simonen and Mikkola 1980). The flysch-like turbidites of the Kalevian Group overlie the Jatulian formations unconformably (Väyrynen 1933) and grade eastwards into epicontinental sediments and volcanics corresponding to the Suysarian of Soviet geologists. It is worth considering that Kalevian (Suysarian) volcanism developed into the same structures as Jatulian volcanism (Svetov 1980).

In Lapland, the Kalevian is only represented by continental or paralic molasse-like deposits including the Latvajärvi felsic volcanics dated at $1.89 \mathrm{Ga}$ and the Kellostapuli and Ylläs con- glomerates, of which granite pebbles yielded 1.93 to $2.06 \mathrm{Ga}$ ages (Rastas 1980).

On account of the $1.9-2.0 \mathrm{Ga}$ age of the Belomorian orogeny, it follows that the Kalevian Group comprises both turbidites of the Svecofennian geosyncline and molasse deposits of the Belomorides. In conclusion:

(1) The Svecofennides followed slightly after the Belomorides, and the Svecofennian geosynclinal stage corresponded closely to the Belomorian collisional stage. Thus, the molasse arising from the peneplanation of the Belomorian fold belt is likely to be found in the Svecofennian geosyncline.

(2) The nature of the Suysarian sediments shows that an epicontinental environment was maintained in Karelia during the Svecofennian cycle and that the Jatulian rift structures were still active. Thus the "Karelian medium massif» (Kharitonov 1966) corresponded to a passive continental crust between two time-spaced mobile belts.

(3) As the Jatulian (= Karelian) belongs to the Belomorian geotectonic assemblage it must be dissociated from the Svecofennides and, consequently, the term "Svecokarelian» orogeny becomes meaningless.

\section{Metamorphic and tectonic evolution}

The structure of the different units involved in the Belomorian fold belt corresponds on the whole to a volcano-sedimentary wedge located at the junction of two continental masses (Fig. 2 ). The dominant structural trends of the axial zone (Tana and Granulite belts) are characterized by $\mathrm{N}-\mathrm{S}$ directions in its northern part and by $\mathrm{E}-\mathrm{W}$ directions in the south, thereby defining an arcuate pattern. The major foliation planes are gently dipping in the west and become progressively steeper to almost sub-vertical in the east. This structure results from three main deformation phases synchronous with granulitegrade metamorphism (Barbey et al. 1977, 1980). 
The first phase, which is recorded only in metapelites, is marked either by composite banding or by residual schistosity preserved in garnet porphyroblasts. It is associated with prograde mineral assemblages such as biotite + sillimanite + quartz + graphite and hercynite + quartz. These parageneses together with the lack of either the muscovite + quartz association or anatexis permit only a rough estimate of the $\mathrm{P}-\mathrm{T}$ conditions in the range $5-7 \mathrm{~Kb}$ and from $600^{\circ}$ to $700^{\circ} \mathrm{C}$, with $\mathrm{X}_{\mathrm{H}_{2} \mathrm{O}}<0.4$ (Fig. 9).

The second phase corresponds to a major tectonic event characterized by tangential movements caused by overthrusting of the InariKola craton onto the South Lapland-Karelia craton. This led to the development of isoclinal westward-facing folds associated with inverse shear zones and with major axial plane schistosity. The deformation was most intense at the base and top of the Granulite belt. This second phase is contemporaneous with the peak metamorphic conditions. The diagnostic parageneses are: garnet + sillimanite $+\mathrm{K}$-feldspar (without anatexis) in pelitic rocks and garnet + clinopyroxene + plagioclase in mafic rocks with $\mathrm{X}_{\mathrm{Mg}}<0.5$ and orthopyroxene + plagioclase in the others. Fluid inclusion density measurements on pelitic gneisses (Mohammed 1972; Klatt 1980; Barbey 1982) and thermobarometry of mafic granulites (Convert 1981; Barbey 1982; Raith et al. 1982; Newton and Perkins 1982) suggest that the $\mathrm{P}-\mathrm{T}$ conditions prevailing during the paroxysmic stage were $7.5 \mathrm{~Kb}, 800^{\circ} \mathrm{C}$ and $\mathrm{X}_{\mathrm{H}_{2} \mathrm{O}} \sim 0.2$ (Fig. 9). Slightly higher pressures $(9-10 \mathrm{~Kb})$ have been reported for the Kandalaksha granulites (Krylova et al. 1982). The deformation continued for a while and was associated with slight rehydration leading to local growth of biotite (especially in the pressure shadows of the garnet porphyroblasts) and hornblende.

The third deformation phase generated gravity structures (normal ductile shear zones and folds overturned to the east) and was accompanied by a gradual decrease in pressure and by local increases in $\mathrm{X}_{\mathrm{H}_{2} \mathrm{O}}$ giving rise to cordieritebearing anatexites. This first retrograde stage is documented by several granulite grade pelitic assemblages (garnet + cordierite + sillimanite, garnet + cordierite + biotite + K-feldspar + sillimanite, garnet + cordierite + orthopyroxene \pm anthophyllite) permitting the mean $\mathrm{P}-\mathrm{T}$ conditions to be estimated at $5.5 \mathrm{~Kb}$ and $750^{\circ} \mathrm{C}$ with $\mathrm{X}_{\mathrm{H}_{2} \mathrm{O}} \sim 0.5$ (Fig. 9).

Late metamorphic recrystallizations occurred in the amphibolite and greenschist facies (retrograde stage 2). They include (Fig. 9):

- cordierite + biotite + andalusite $+\mathrm{K}$ feldspar, garnet + biotite + andalusite and garnet + biotite yielding a $\mathrm{P}-\mathrm{T}$ estimate of about $3 \mathrm{~Kb}$ and $550^{\circ} \mathrm{C}$;

- prehnite + epidote + chlorite + quartz and aqueous fluid inclusions with $25 \% \mathrm{NaCl}$ implying a pressure lower than $2 \mathrm{~Kb}$ and a temperature near $350^{\circ} \mathrm{C}$. The late deformation stages are characterized by upright angular folds and shearing (Wright et al. 1978).

What is more, geophysical studies in the Inari-Kola craton show (1) the existence at low structural levels of nearly horizontal reflection surfaces that may be interpreted as flat-lying shear zones suggesting large-scale intracrustal tangential movements (Kratz 1978), and (2) paleomagnetic results compatible with plate motion since the Early Proterozoic (Pesonen and Neuvonen 1981). The Belomorides mobile belt is therefore considered to have resulted from the collision of two continental masses previously separated by a geosynclinal basin and so can be defined as a collisional orogen. From the pressure-temperature estimates in the two highgrade belts constituting the axial zone (Tana and Granulite belts) compared with those in the adjacent areas it is evident that:

(1) The piezothermic array drawn from the $\mathrm{P}-\mathrm{T}$ location of the various retrograde mineral assemblages, convex to the temperature axis, is consistent with a model of isostatic readjustment and approaches a geotherm (Fig. 9). 


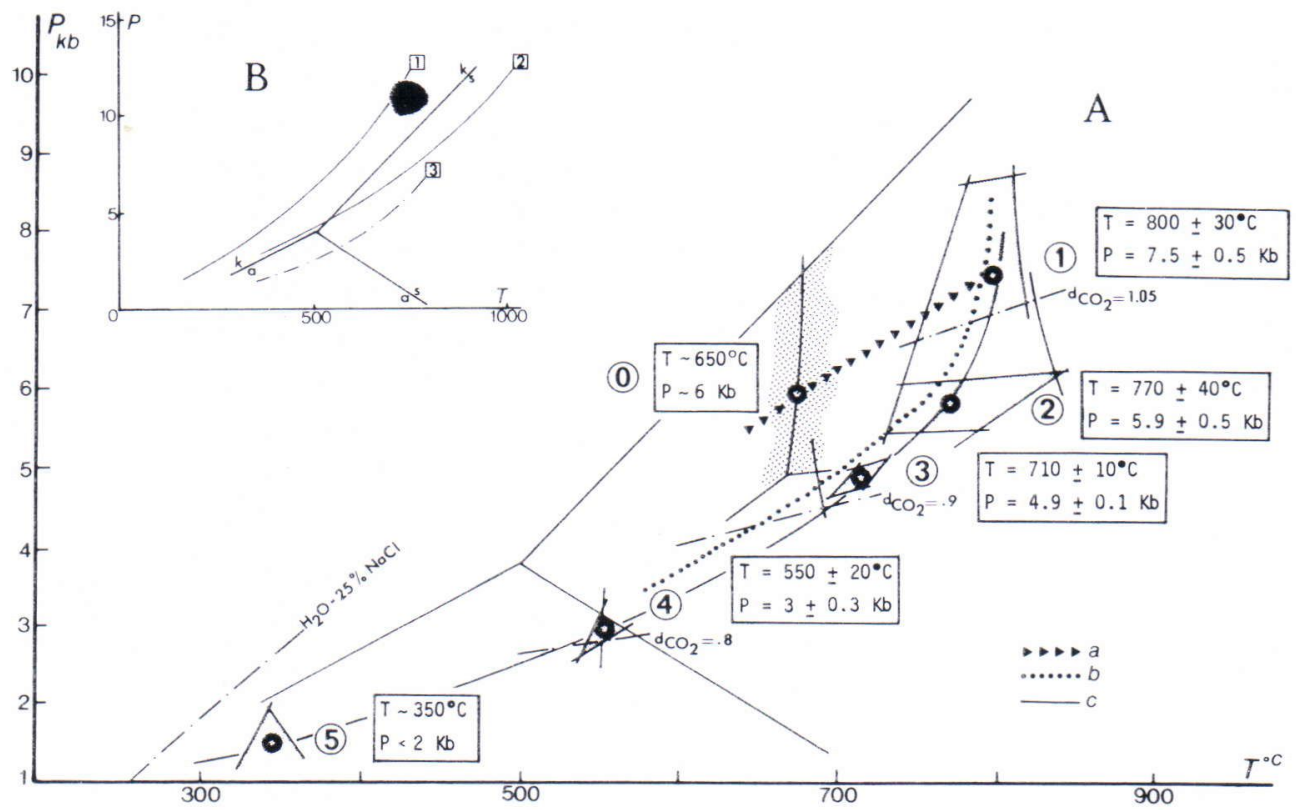

Fig. 9. General P-T diagram for the Lapland granulites (modified after Barbey 1982) showing (A) the P-T regimes of the three stages of the regional metamorphism and (B) the probable existence of two distinct geotherms. See explanations in the text. The relevant mineral reaction curves and geotherms are as follows.

Diagram $A$

Prograde stage (O) Garnet-in curve from Bi+Sill $+Q$ without $\mathrm{Cd}$, for $X_{M g}^{G t}=0.45$ and $X_{\mathrm{H}_{2}} \mathrm{O}=0.2 ; \mathrm{Bi}$-Sill-Cd curve from Holdaway and Lee (1977) and Cd-Gt-Sill curve from Newton and Wood (1979).

Paroxysmic stage (1) Alkali-feldspar solvus critical curve (Parsons, 1978); minimum granite melting for $\mathrm{X}_{\mathrm{H}_{2} \mathrm{O}}$ $=0.1$ (Kerrick, 1972); Gt-Cpx-Opx-Plag curve for $\mathrm{X}_{\mathrm{Mg}}^{\mathrm{rock}}=0.67$ (Irving 1974); Gt-Opx geobarometers (Newton and Perkins 1982 assuming $\mathrm{T}=800^{\circ} \mathrm{C}$ ); $\mathrm{Gt}-\mathrm{Cpx}$ geothermometer (Ellis and Green 1979); isochore $(\mathrm{d}=1.05) \mathrm{for}_{\mathrm{CO}}$ densities (Kerrick and Jacobs 1981).

Retrograde stage $I$ (2) $\mathrm{Cd}-\mathrm{Gt}-$ Sill curve in diatexites for $\mathrm{X}_{\mathrm{Mg}}^{\mathrm{Gt}} / \mathrm{X}_{\mathrm{Mg}}^{\mathrm{Cd}}=1.81$ to 2.26 and $\mathrm{X}_{\mathrm{H}_{2} \mathrm{O}}=0.5$ (Newton and Wood (1979); alkali-feldspars solvus critical curve (Parsons 1978; minimum tholeiite melting for $\mathrm{X}_{\mathrm{H}_{2} \mathrm{O}}=0.5$ (Holloway and Burnham (1972); higher P-T values for the An-Sill-Gros assemblages given by Hörmann et al. (1980).

(3) $\mathrm{Gd}-\mathrm{Gt}-\mathrm{Bi}-\mathrm{Sill}-\mathrm{KF}$ assemblages in metatexites for $\mathrm{X}_{\mathrm{Mg}}^{\mathrm{Gt}}=0.26$ and $0.31, \mathrm{X}_{\mathrm{Mg}}^{\mathrm{Cd}}=0.74$ and 0.78 and $\mathrm{X}_{\mathrm{H}_{2} \mathrm{O}}$ $=0.5$ to 0.7 (Holdaway and Lee 1977; Newton and Wood (1979); minimum granite melting for $\mathrm{X}_{\mathrm{H}_{2} \mathrm{O}}=0.5($ Kerrick (1972); isochore $(\mathrm{d}=0.9)$ for $\mathrm{CO}_{2}$ densities (Kerrick and Jacobs 1981).

Retrograde stage II (4) $\mathrm{Cd}-\mathrm{And}-\mathrm{Bi}-\mathrm{KF}$ for $\mathrm{X}_{\mathrm{Mg}}^{\mathrm{Cd}}=0.2$ and $\mathrm{X}_{\mathrm{H}_{2} \mathrm{O}}=0.5$ (Holdaway and Lee 1977); $\mathrm{Mu}-\mathrm{Q}-$ $\mathrm{KF}-\mathrm{Al}_{2} \mathrm{SiO}_{5}$ for $\mathrm{X}_{\mathrm{H}_{2} \mathrm{O}}=0.5$ (Kerrick 1972): $\mathrm{Bi}-\mathrm{Gt}$ geothermometer (Ferry and Spears 1978); isochore $(\mathrm{d}=0.8)$ for $\mathrm{CO}_{2}$ densities (Kerrick and Jacobs 1981).

(5) Prehn-Chl-Ep-Q assemblages (Winkler 1976); isochore for $\mathrm{H}_{2} \mathrm{O}-25 \% \mathrm{NaCl}$ densities (Hilbert 1979).

Diagram B

$\mathrm{Al}_{2} \mathrm{SiO}_{5}$ phase diagram for Holdaway (1971); $\mathrm{P}-\mathrm{T}$ regime of the Belomorian metamorphism in the cratonic domains after Kratz (1978) (dashed area);

1) Early Proterozoic continental geotherm (O'Hara 1977); 2) Archean geotherm (O'Hara 1977; Condie 1981);

3) Piezothermic array of the Lapland granulites.

(2) The dT/dP gradient prevailing during peak metamorphism in both the Tana and Granulite belts is higher than those recognized in the adjacent cratons, which are characterized by overall kyanite stability (Mikkola 1941; Kratz
1978; Krill, written comm. 1982) and from which eclogitic occurrence have been reported (von Gaertner 1966). Such differences indicate the existence of two distinct geotherms: one in the cratonic domains similar to the early Prote- 
rozoic continental geotherm of O'Hara (1977), and one in the axial zone, close to the Archean geotherm (O'Hara 1977; Condie 1981). This suggests that a thermal anomaly was located beneath the Belomorian geosyncline (strongly convective mantle?).

\section{Discussion}

From data available on the origin and relationships of the rock units, we shall attempt to examine the larger question of the role of plate tectonics in the evolution of the continental crust of the Baltic Shield during the early Proterozoic. Although some authors consider that the continental lithosphere generated in the Archean evolved during the early Proterozoic predominantly by intracrustal processes, several active continental margins of a modern type have been recognized, and it has been suggested that the Wilson cycle has been operating since at least $1.8 \mathrm{Ga}$ (Hoffman 1980; Baragar and Scoates 1981; Gibb 1983). Hence, the recognition in the Belomorides of rock assemblages characterizing both passive and active continental margins is a strong indication that Wilson-cycle processes have governed the development of the Belomorian mobile belt.

Several outstanding features constrain the reinterpretation of the whole Belomorides. The first is the fact that the Jatulian formations belong to the Belomorian fold belt on the basis of their geochronology, sedimentary facies and tectonic and metamorphic patterns. This sequence of transitional to shelf sediments and volcanics situated on both sides of the belt gives the Belomorides a prominent symmetrical aspect. The other features relative to the axial part of the mobile belt are as follows:

- diachronous magmatic activity extending throughout the evolution of the belt;

- the formation of a geosyncline initiated by intense, mainly basaltic volcanism and subsequently filled with a flysch-like sedimentary se- quence, and lacking the typical shelf sediments generally found in the Proterozoic intracratonic basins and aulacogens (e.g. Circum-Ungava geosyncline, Damara aulacogen and Mount Isa geosyncline);

- marked asymmetrical plutonism restricted to the Inari-Kola craton comprising both foliated and undeformed plutons emplaced in the range $1.9-2.0 \mathrm{Ga}$, similar to present-day Cordilleran magmatism;

- structural asymmetry imposed by an orogenic event $1.9-2.0 \mathrm{Ga}$ ago and characterized by major tangential displacements and granulitegrade metamorphic recrystallizations, related to the collision of two continental blocks.

The Tana and Granulite belts and the Jatulian formations emphasize the peculiar structure and evolution of the Belomorian geosyncline. Whereas its symmetrical pattern is reminiscent of early Proterozoic intracratonic basins, intense geosynclinal sedimentation and volcanism, large-scale tangential tectonics (nappe tectonics according to von Gaertner 1964) and widespread plutonism in the overthrust basement unit (Inari-Kola craton) distinguish it from ensialic orogens but make it rather relevant to active margins.

The interpretation of the Belomorian fold belt in a plate tectonic framework involving the formation of a geosyncline and resulting in the breakup of a single, old continental crust into two plates, followed by a continental collision leads us to examine whether a new oceanic crust was created and whether subduction occurred during the geosynclinal phase. Although there is no definitive answer, several arguments favour a process of oceanization.

(1) The existence of a positive thermal anomaly beneath the Belomorian geosyncline, the nature of the tholeiitic volcanics resembling in some respects oceanic tholeiites and the intensity of this diachronous magmatic activity that in fact extends for more than $500 \mathrm{~km}$ across the belt despite strong crustal shortening, betray mantle activity and crustal fragmentation clear- 
Table 6. Successive stages in the development of the Belomorian fold belt. Compiled from Martin et al. (1981, 1983), Silvennoinen (1980), Meriläinen (1976), Bernard-Griffiths et al. (1984) and Barbey (1982).

\begin{tabular}{lll}
\hline AGE $_{(\mathrm{Ga})}$ & $\begin{array}{l}\text { JATULIAN FORMATIONS OF KARELIA AND } \\
\text { KOLA PENINSULA (platform and rifts) }\end{array}$ & $\begin{array}{l}\text { TANA AND GRANULITE BELTS } \\
\text { (geosyncline) }\end{array}$ \\
\hline 1.8 & $\begin{array}{l}\text { Sedimentation of molasse-type deposits (attributed } \\
\text { to the Kalevian group) in the south of the Granulite } \\
\text { belt, comprising the Latvajärvi felsic volcanics } \\
(1.88 \mathrm{Ga}) \text { and various conglomerates (e.g. Kellosta- } \\
\text { puli, Ylläs). }\end{array}$ & $\begin{array}{l}\text { Uplift and erosion of the Belomorian fold belt, the } \\
\text { detritus filling the contemporaneously existing Sve- } \\
\text { cofennian geosyncline. Late deformation and meta- } \\
\text { morphic recrystallizations. }\end{array}$
\end{tabular}

Greenschist to amphibolite facies metamorphic recrystallizations. Opening of the Svecofennian geosyncline.

Emplacement of synkinematic to postkinematic dioritic to granitic plutons in the Inari-Kola craton (Cordilleran-type plutonism).
The third period of deformation (gravity structures) associated with granulite facies retrograde mineral assemblages and migmatization.

The second period of deformation resulting from the collision of the Inari-Kola craton with the South Lapland-Karelia craton. Peak metamorphic conditions. Syngranulitic calc-alkaline and tholeiitic plutonism (charnockitic complex and anorthositic massifs).

The first period of deformation and the prograde stage of metamorphism resulting from the subduction of the ocanic crust. Calc-alkaline magmatism in the Inari-Kola craton.

Geosynclinal filling with flysch-like terrigenous sediments and a continuing tholeiitic volcanic activity (khondalite suite).

Geosynclinal period initiated by an intense calcalkaline and tholeiitic volcanism (Tana belt).

2.2 Middle Jatulian deposits and the second volcanic episode.

2.3 General uplift of the continental crust in Karelia and Kola Peninsula.

Emplacement of transitional sediments and the first volcanic episode (alkaline volcanism).

$2.4 \quad$ Continental rifting and formation of fault-bounded basins (Pechenga-Varzuga rift, Kuolajärvi-Windy belt).

2.4 Formation of a continental rise and emplacement of stratified gabbroic massifs in southern Lapland (Kemi, Syöte) and Kola Peninsula (Paana, Monchegorsk).

2.5 Late pink granites associated with the greenstone with the greenstone belts of Karelia. Emplacement of the Sariolian sediments and volcanics.

Archean crustal evolution
Ductile spreading. Emplacement of early granitoids (2.36 Ga). Hypothetical rifting (not recorded) at the site of the future geosynclinal. ly different from those encountered in aulacogen-like settings.

(2) The restricted character of the bimodal volcanism in the Tana belt implies sufficient opening to limit the crust-mantle interaction.

(3) The great extension of the lateral Jatulian rift basins (the supracrustals of the PechengaVarzuga rift spread nowadays $30 \mathrm{~km}$ wide) gives 
clear indications on the extent of the opening in the central part of the mobile belt and thus supportes the high probability of oceanization.

Most of the field and chemical data contradict the subduction of oceanic crust during the filling of the Belomorian geosyncline. The main arguments are: the lack of piedmont formations in the metasedimentary sequence, which in other respects is similar to Atlantic-type sediments, the presence of continental shelves on both sides of the basin, the absence of obvious marginal calc-alkaline volcanism and the origin of the calc-alkaline charnockitic plutonics inconsistent with the melting of MORB-type basalts. It seems likely, however, that the subduction took place later, just before the collision. This is indicated by (1) the asymmetry and the abundance of early Proterozoic foliated calcalkaline dioritic to granodioritic plutons restricted to the Inari-Kola craton and (2) the existence in the metasedimentary granulites of prograde assemblages associated with earlier foliation, both predating the collisional event. This cordilleran-type calc-alkaline magmatism, ranging from gabbro to granite, strongly favours the subduction of a wet oceanic crust (lowering melting temperatures in the overlying mantle wedge). This is a fundamental difference from many Precambrian mobile belts, which seem to be almost completely devoid of such subductionrelated calc-alkaline magmatism. Since metamorphism and deformation occurred over the range $1.9-2.0 \mathrm{Ga}$, the whole oceanic crust must have been subducted in less than $100 \mathrm{Ma}$ (i.e. within the limits of analytical uncertainty).

Another significant difference from ensialic mobile belts is the typical monocyclicity of the Belomorian tectono-metamorphic event, whereas up to three thermal events have been recorded in the intracontinental Damara belt (Kröner 1982). Note also that crustal shortening is not confined to the margin of the belt but extends for several hundred kilometres within the overriding plate.

Finally, the synchronism between the colli- sion in the Belomorides (displaying a westwardfacing vergency) and the opening of the Svecofennian geosyncline implies relative displacement and subduction of the Karelian continental crust to the east.

The conditions imposed by the above considerations prompt the following speculations on the development of the Belomorides (see also Table 6 and Fig. 10). Originating in an asthenospheric belt system (see for example Zorin 1981), subsidence was initiated in an eroded Archean sialic crust by crustal stretching. A first phase of rifting $(2.4-2.2 \mathrm{Ga})$ led to the formation of the fault-bounded troughs of Karelia and Kola Peninsula (abortive rifting phase ?). Further crustal spreading and continuous heating of the lower crust produced considerable thinning of the continental crust. This ruptured, giving rise to a geosyncline floored by oceanic crust and edged by two continental shelves (passive margin). The geosynclinal period $(2.1-2.0 \mathrm{Ga})$ culminated with the deposition of a terrigeneous sedimentary sequence and with tholeitic volcanism. The closure $(2.0-1.9 \mathrm{Ga})$, followed by subduction of the oceanic crust (Cordilleran-type plutonism, early deformation and metamorphic recrystallizations), ended with continental collision (tangential tectonics, peak metamorphic conditions). This probably resulted from horizontal compression related to eastward motion of the Karelian plate (= Karelian medium massif) by the combined effect of (1) the subduction of the oceanic crust through spontaneous instability (Hynes 1982) and (2) the opening of the Svecofennian geosyncline. Finally, the erosion of the Belomorian fold belt gave rise to molassic deposits of the Kalevian Group (1.9-1.8 Ga).

\section{Conclusions}

(1) The Lapland granulites together with the Tana formations constitute an overall $\mathrm{N}-\mathrm{S}$ trending high-grade belt occupying the axial zone of the early Proterozoic Belomorian fold 


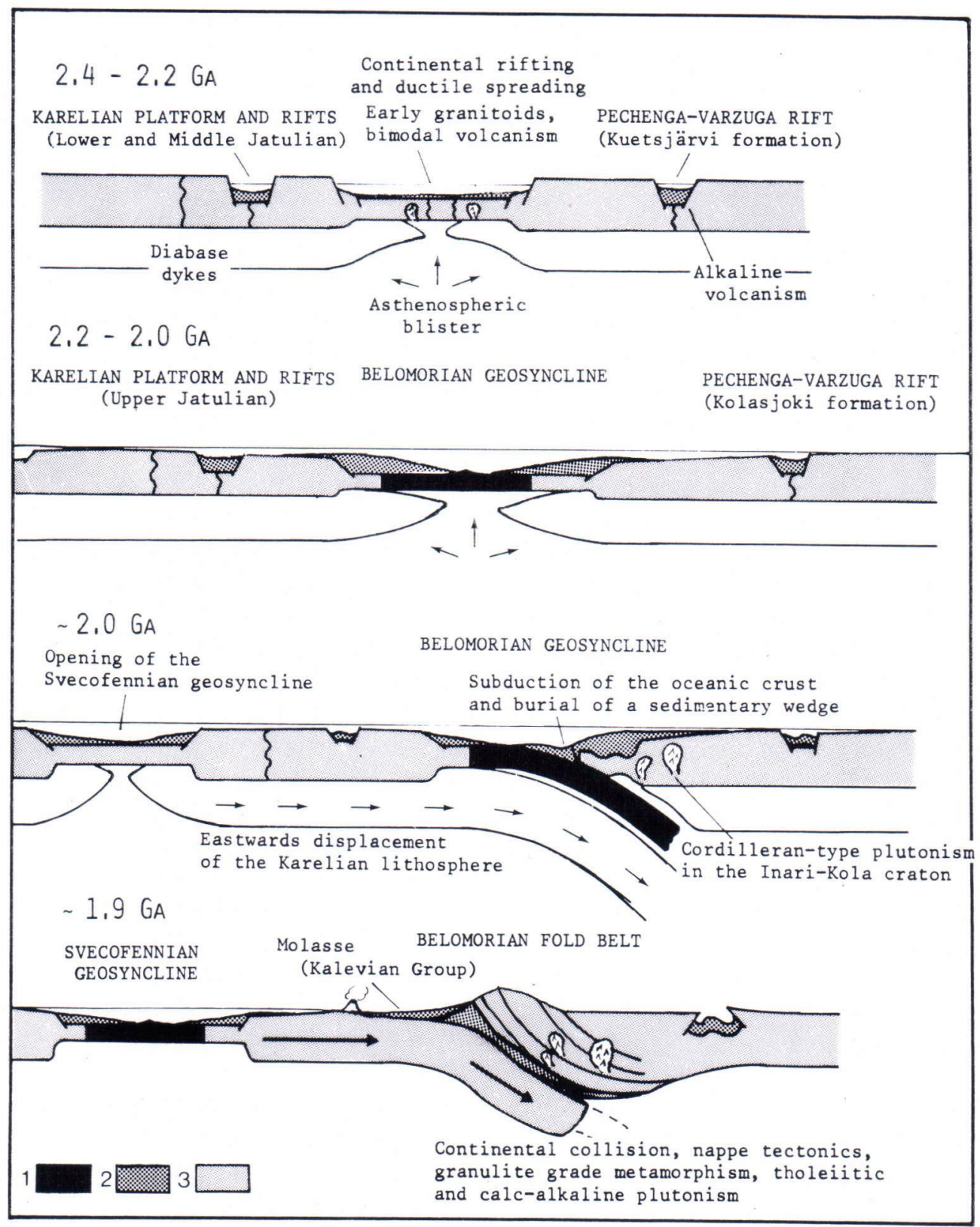

Fig. 10. Hypothetical evolution of the Belomorian orogenic belt. Modified after Barbey (1982).

1) Oceanic crust; 2) Volcanic and sedimentary formations; 3) continental crust. Not to scale.

belt (1.9-2.4 Ga). Allowing for lithological, metamorphic and structural features characteristic of geosynclinal formations, they are believed to represent the suture of the fold belt.
The surrounding parts are mainly composed of intensely reworked Archean material and of early Proterozoic supracrustals that corresponded to two continental domains (Inari-Kola 
and South Lapland-Karelia cratons) with their epicontinental covers (Jatulian).

(2) Re-interpreted in terms of a Wilson cycle as a collisional orogen, the Belomorides are thought to represent an intermediate case between an intracontinental mobile belt orogeny and a modern active plate margin. The lithology and the salient symmetry of the Belomorian sedimentary basin together with the absence of subduction during the geosynclinal period are rather consistent with what we know about ensialic orogens (Kröner 1977), thereby suggesting that the Belomorides proceeded from the reactivation and the breakup of a single Archean craton. But the nature and extent of the geosynclinal magmatism and sedimentation, the large-scale tangential movements and the widespread cordilleran-type plutonism in the Inari-Kola craton (viz. the overriding plate) evoke present-day marginal orogeneses. The Belomorides, which display close analogies with well established Upper Proterozoic and Phanerozoic collisional chains such as the HoggarIforas segment (Caby et al. 1981) and the Northern Appennines (Kligfield 1979), appear to be the oldest fold belt in which a suture has been recognized, and suggest that the Wilson cycle has been active since at least $2.1-2.0 \mathrm{Ga}$.

(3) Finally, increased stability of the oceanic

\section{References}

Arth H. J. G. \& Hanson G. N., 1975. Geochemistry and origin of the early Precambrian crust of northeastern Minnesota. Geochim. Cosmochim. Acta 39, 325-362.

Auvray B.; Blais S.; Jahn B. M. \& Piquet D., 1982. Komatiites and komatiitic series of the Finnish greenstone belts. In: N.T. Arndt and N. Nisbet (Ed.), George Allen and Unwin, London, 131-146.

Bailey J. C., 1981. Geochemical criteria for a refined tectonic discrimination of orogenic andesites. Chem. Geol. 32, 139-154.

Baragar W. R. A. \& Scoates R. F. J., 1981. The CircumSuperior belt: A Proterozoic plate margin? In: A. Krö- tectosphere, the growing scarcity of crust-mantle decoupling, and the interaction of large-sized plates related to progressive cooling of the mantle (Hargraves 1981; Hynes 1982) might account for the gradual but diachronous change in the sites of formation of the granulite belts from intracontinental mobile belts to active plate margins. In this respect, the Lower Proterozoic is a period during which highly divergent mobile belts coexisted: from primitive types close to Archean evolution like the Transamazonian segment in French Guyana (Marot and Capdevila 1982) to astonishingly modern fold belts like the Belomorides through the widespread African intracontinental mobile belts.

Aknowledgements. The field work was financed under a cooperative reseach agreement between the Academy of Finland and the French »Ministère des Relations Extérieures». The research was also supported by the project ATP Géodynamique. We are indebted to the Geological Survey of Finland for their kind cooperation and to the Centre Culturel Français in Helsinki for their technical assistance.

Helpful discussions with and comments by J.M.L. Bertrand, P. Choukroune, G. Gaàl, R.W. Nesbitt, J. Touret and $\mathrm{Ph}$. Vidal are gratefully appreciated. We would also like to extend our thanks to F. Vidal and R. Montanari for the chemical analyses and to N. Grandidier for typing the manuscript. ner (Ed.), Precambrian Plate Tectonics, Elsevier, Amsterdam, 1-20.

Barbey P., 1982. Signification géodynamique des domaines granulitiques. La ceinture des Granulites de Laponie (Fennoscandie): Une suture de collision continentale d'âge protérozorque inférieur (2.3-1.9 Ga). Reconstitution pétrologique et géochimique. Thèse d'Etat, Univ. de Nancy I, 346 p.

Barbey P.; Capdevila R.; Choukroune P. \& Hameurt J., 1977. Structure de la virgation granulitique de Laponie. C. R. Acad. Sci. Paris 284, 1967-1970.

Barbey P.; Convert J.; Martin H.; Moreau B.; Capdevila R. \& Hameurt J., 1980. Relationships between granitegneiss terrains, greenstone belts and granulite belts in 
the Archean crust of Lapland (Fennoscandia). Geol. Rundschau 69, 648-658.

Barbey P.; Capdevila R. \& Hameurt J., 1982 a. Major and transition trace element abundances in the Khondalite suite of the Granulite belt of Lapland (Fennoscandia): Evidence for an early Proterozoic flysch-belt. Precambrian Res. 16, 273-290.

Barbey P.; Touret L.; Capdevila R. \& Hameurt J., 1982 b. Mise en évidence de deux séries paléo-volcaniques dans la ceinture protérozoique de la Tana. Conséquences sur l'environnement géotectonique de la ceinture des Granulites de Laponie (Fennoscandia). C. R. Acad. Sci. Paris 294, 207-210.

Barbey P. \& Cuney M. K., 1982. Rb, Sr, Ba, U and Th geochemistry of the Lapland Granulites. LILE fractionation controlling factors. Contrib. Mineral. Petrol. 81, 304-316.

Barton J. M. Jr \& Key R. M., 1981. The tectonic development of the Limpopo mobile belt and the evolution of the Archean cratons of southern Africa. In: A. Kröner $(E d$.$) , Precambrian Plate Tectonics, Elsevier, Amster-$ dam, 185-207.

Bernard-Griffiths J.; Peucat J. J.; Postaire B.; Vidal P.; Convert J. \& Moreau B., 1984. Isotopic data (U-Pb, $\mathrm{Rb}-\mathrm{Sr}, \mathrm{Pb}-\mathrm{Pb}$ and $\mathrm{Sm}-\mathrm{Nd}$ ) of mafic granulites from Finnish Lapland. Precambrian Res. 23, 325-348.

Bibikova E. V.; Tugarinov A. I.; Gracheva T. V. \& Konstantinova $M$. V., 1973. The age of granulites of the Kola Peninsula. Geokhimiya, SSSR 5, 664-675.

Blais S.; Auvray B.; Capdevila R.; Jahn B. M. \& Hameurt $J ., 1978$. The Archean greenstone belts of Karelia (Eastern Finland) and their komatiitic and tholeiitic series. In: B. F. Windley and S. M. Naqvi (Ed.), Archean Geochemistry, Elsevier, Amsterdam, 87-107.

Caby R.; Bertrand J. M. L. \& Black R., 1981. Pan-African ocean closure and continental collision in the Hoggar Iforas segment, Central sahara. In: A. Kröner (Ed.), Precambrian Plate Tectonics, Elsevier, Amsterdam 407-434.

Condie K. C., 1981. Archean greenstone belts. Developments in Precambrian Geology, 3, Elsevier, Amsterdam.

-, 1982. Early and Middle Proterozoic supracrustal successions and their tectonic settings. Amer. J. Sci. 282, $341-357$.

Convert J., 1981. Les granulites à orthopyroxènes de Laponie (Finlande et Norvège). Pétrologie et géochimie. Thèse, Univ. de Rennes, 120 p.

Coward M. P., 1980. Shear zones in the Precambrian crust of southern Africa. J. Structural Geol. 2, 19-27.

Ellis D. E. \& Green D. H., 1979. An experimental study of the effect of $\mathrm{Ca}$ upon garnet-clinopyroxene $\mathrm{Fe}-\mathrm{Mg}$ exchange equilibria. Contrib. Mineral. Petrol 71, 13-22.
Eichelberger J. C., 1978. Andesitic volcanism and crustal evolution. Nature 275, 21-27.

Engel A. E. J.; Itson S. P.; Engel C. G.; Stickney D. M. \& Cray E. J. Jr, 1974. Crustal evolution and global tectonics: a petrogenetic view. Bull. Geol. Soc. Amer. 85, $843-858$.

Eskola P., 1952. On the granulites of Lapland. Amer. J. Sci., Bowen vol. 1, 133-171.

Ferry J. M. \& Spears F. S., 1978. Experimental calibration of the partitioning of $\mathrm{Fe}$ and $\mathrm{Mg}$ between biotite and garnet. Contrib. Mineral. Petrol. 66, 113-117.

Gaàl G., 1982. Proterozoic evolution and the late Svecokarelian plate deformation in the Central Baltic Shield. Geol. Rundschau 71, 158-170.

Gaàl G.; Mikkola A. \& Söderholm B., 1978. Evolution of the Archean crust in Finland. Precambrian Res. 6, 199-215.

Gaertner H. R. von, 1964. Gedanken zur Tektonik der lappländischen Granulite. Bull. Comm. geol., Finlande 204, V 207-217.

-, 1966. International geological map of Europa Sheet D-2. Second edition. UNESCO and Bundesanstalt für Bodenforschung.

Gibb R. A., 1983. Model for suturing of Superior and Churchill plates: an example of double indentation tectonics. Geology 11, 413-417.

Hargraves R. B., 1981. Precambrian tectonic style: A liberal uniformitarian interpretation. In: A. Kröner ( $E d$.), Precambrian Plate Tectonics, Elsevier, Amsterdam, $21-56$.

Hilbert R., 1979. PVT Daten von Wasser und von wässerigen Natriumchlorid. Lösungen bis $873 \mathrm{~K}, 4000$ bar und 25 Gewichtperzent $\mathrm{NaCl}$. Hochschul verlag Freiburg, Dr Ing., Universität Fridericiana, Karlsruhe, 212 p.

Hoffman P., 1980. Wopmay orogen: A Wilson cycle of early Proterozoic age in northwest of the Canadian shield. Geol. Ass. Canada, Spec. Paper 20, 523-549.

Holdaway M. J., 1971. Stability of andalusite and the aluminium silicate phase diagram. Amer. J. Sci. 271, 97-131.

Holdaway M. J. \& Lee S. M., 1977. Fe-Mg cordierite stability in high grade pelitic rocks based on experimental, theoretical and natural observations. Contrib. Mineral. Petrol. 63, 175-198.

Holloway J. R. \& Burnham C. W., 1972. Melting relation of basalt with equilibrium water pressure less than total pressure. J. Petrology 13, 1-30.

Hormann P. K.; Raith M.; Raase P.; Ackermand D. \& Seifert $F$., 1980. The granulite complex of Finnish Lapland: Petrology and metamorphic conditions in the Ivalojoki-Inarijärvi area. Bull. Geol. Surv. Finland 308.

Hynes A., 1982. Stability of the oceanic tectosphere - a model for early Proterozoic intracratonic orogeny. Earth Planet. Sci. Letters 61, 333-345. 
Irving A. J., 1974. Geochemical and high pressure experimental studies of garnet pyroxenite and pyroxene granulite xenoliths from the Delegate basaltic Pipes, Australia. J. Petrology 15, 1-40.

Jahn B. M.; Auvray B.; Blais S.; Capdevila R.; Cornichet J.; Vidal P. \& Hameurt J., 1980. Trace element geochemistry and petrogenesis of Finnish greenstone belts. J. Petrology 21, 201-244.

Jakes P. \& Gill J., 1970. Rare earth elements and the island arc tholeiitic series. Earth Planet. Sci. Latters 9, 17-28.

Jakes P. \& White A. J. R., 1970. K-Rb ratios of rocks from island arc areas. Geochim. Cosmochim. Acta 34, $849-856$.

Katz M. B., 1976. Early Precambrian granulites - greenstones transform mobile belts and ridge - rifts of early crust? In: B. F. Windley (Ed.), The Early History of the Earth, J. Wiley, New-York, 147-155.

-, 1977. Metasediments in Archean granulite facies belts and their tectonic setting. In: A. V. Sidorenko (Ed.), Correlations of the Precambrian, Moscow, 26-29.

Kerrick D. M., 1972. Experimental determination of muscovite + quartz stability with $\mathrm{P}_{\mathrm{H}_{2} \mathrm{O}}<\mathrm{P}_{\text {tot. }}$ Amer. J. Sci. 272, 946-958.

Kerrick D. M. \& Jacobs C. K., 1981. A modified RedlichKwong equation for $\mathrm{H}_{2} \mathrm{O} \mathrm{CO}_{2}$ and $\mathrm{H}_{2} \mathrm{O}-\mathrm{CO}_{2}$ mixtures at elevated pressures and temperatures. Amer. J. Sci. 281, 735-767.

Kharitonov L. Y., 1966. Struktura stratigrafiya Karelid vostochnoi chasti Baltiiskogo shchita. Materialy po geologii i poleznym iskopayemym Svero-zapada. Izd-vo, Nedra, 8 .

Klatt E., 1980. Seriengliederung, Mineralfazies und Zusammensetzung der Flüssigkeiteinschlüsse in der präkambrischen Gesteinserien Nordlapplande. Doktor. Dissert., Universiteit Kiel, 125 p.

Klifield R., 1979. The Northern Apennines as a collisional orogen. Amer. J. Sci. 279, 676-691.

Kratz K. O. (Ed.), 1978. The continental crust of the eastern part of the Baltic Shield (in Russian). Nauka Publ., Leningrad $231 \mathrm{p}$.

Kroner A., 1977. Precambrian mobile belts of southern and eastern Africa. Ancient sutures or sites of ensialic mobility? A case for crustal evolution towards plate tectonics. Tectonophysics 40, 101-135.

-, 1981. Precambrian plate tectonics. In: A. Kröner (Ed.), Precambrian Plate Tectonics, Elsevier, Amsterdam, $57-90$.

-, 1982. $\mathrm{Rb}-\mathrm{Sr}$ geochronology and tectonic evolution of the Pan-African Damara belt of Namibia, Southwestern Africa, Amer. J. Sci. 282, 1471-1507.

Kroner A.; Puustinen K. \& Hickman M., 1981. Geochronology of an Archean tonalitic gneiss dome in northern Finland and its relation with an unusual over- lying volcanic conglomerate and komatiitic greenstone. Contrib. Mineral. Petrol. 76, 33-41.

Krylova M. D.; Felix M. \& Fiala I., 1982. Granate und Orthopyroxene in einem Hochdruck-Granulitkomplex im SW-Teil der Halbinsel Kola. Chem. Erde, 41, 273-291.

Lambert R. St J. \& Holland J. G., 1974. Yttrium geochemistry applied to petrogenesis utilizing calcium-yttrium relationships in minerals and rocks. Geochim. Cosmochim. Acta 38, 1393-1414.

Marot A. \& Capdevila R., 1982. Géologie du Synclinorium Sud de la Guyane française. 9th Caribbean Geol. Conference, Santo Domingo, Dominican Republic. Transactions $1,613-619$.

Martignole J., 1979. Charnockite genesis and the Proterozoic crust. Precambrian Res. 9, 303-310.

Martin H.; Querré G. \& Hameurt J., 1981. Données géochronologiques $\mathrm{Rb}-\mathrm{Sr}$ les granites »tardifs» dans les terrains archéens de finlande orientale. 1rst E.U.G., Strasbourg, Terra Cognita, special issue, 97 (abstract).

Martin H.; Chauvel C.; Jahn B. M. \& Vidal P., 1983 a. $\mathrm{Rb}-\mathrm{Sr}$ and $\mathrm{Sm}-\mathrm{Nd}$ isotopic ages and geochemistry of Archean granodioritic rocks from eastern Finland. Precambrian Res. 20, 79-91.

Martin H.; Chauvel C. \& Jahn B. M., 1983 b. Major and trace element geochemistry and crustal evolution of Archean granodioritic rocks from eastern Finland. Precambrian Res. 21, 159-180.

Martin H. \& Quérré G., 1984. A 2.5 Ga reworked sialic crust. $\mathrm{Rb}-\mathrm{Sr}$ ages and isotopic geochemistry of late Archean volcanic and plutonic rocks from E-Finland. Contrib. Mineral. Petrol 85, 292-299.

Masuda A., 1968. Geochemistry of lanthanides in basalts of central Japan. Earth Planet. Sci. Letters 4, 284-292.

Meriläinen $K$., 1976. The granulite complex and adjacent rocks in Lapland, northern Finland. Bull. Geol. Surv. Finland 281.

-, 1980. On the stratigraphy of the Karelian formations. In: A. Silvennoinen ( $E d$.), Jatulian Geology of the eastern part of the Baltic Shield, Proc. Finnish-soviet symposium, Rovaniemi, 97-112.

Mikkola E., 1941. The general geological map of Finland. Sheets B-7, C-7, D-7, Muonio, Sodankylä, Tuntsajoki. Explanation to the map of rocks. Suomen geol. Toimikunta, Helsinki.

Mohammed L., 1972. Inclusions fluides dans les granulites de Valjok. Mém. D.E.A., Univ. Nancy I, unpubl.

Moreau B., 1980. Pétrologie et géochimie des anorthosites de Laponie (Finlande): Exemple des massifs de Vaskojoki et Mutajärvi. Thèse, Univ. Rennes.

-, 1981. Evolution du massif anorthositique de Vaskojoki, Finlande du Nord. Ann. Soc. Géol. Belgique 104, $261-267$.

Nesbitt R. W.\& Sun S. S., 1976. Geochemistry of Archean spinifex-textured peridotites and magnesian and low- 
magnesian tholeiites. Earth Planet. Sci. Letters 31, 433-453.

Newton R. C. \& Perkins D. III, 1982. Thermodynamic calibration of geobarometers based on the assemblages garnet-plagioclase-orthopyroxene-(clinopyroxene)quartz. Amer. Mineral. 67, 203-222.

Newton R. C. \& Wood B. J., 1979. Thermodynamics of water in cordierite and some petrologic consequences of cordierite as a hydrous phase. Contrib. Mineral. Petrol. 68, 391-405.

Oftedahl C., 1980. Norway. In: Geology of the European countries. 26th Int. Geol. congress, Paris, Dunod, 346-456.

O'Hara M. J., 1977. Thermal history of excavation of Archean genisses from the base of the continental crust. J. Geol. Soc. London 134, 185-200.

Parsons I., 1978. Alkali-feldspars: Which solvus? Phys. Chem. Earth 2, 199-213.

Papunen H.; Idman H.; Ilvonen E.; Neuvonen K. S.; Pihlaja P. \& Talvitie J., 1977. Lapin ultramafiiteista. Summary: The ultramafics of Finland. Geol. surv. Finland, Report of investigation $23,87 \mathrm{p}$.

Pearce J. A., 1976. Statistical analysis of major element patterns in basalts. J. Petrology 17, 15-43.

Perttunen V., 1980. Stratigraphy of the Peräpohja schist area. In: A. Silvennoinen ( $E d$.), Jatulian Geology of the eastern part of the Baltic Shield, Proc. Finnish-soviet Symposium, Rovaniemi, 139-144.

Pesonen L. J. \& Neuvonen K. S., 1981. Paleomagnetism of the Baltic Shield. Implications for Precambrian tectonics. In: A. Kröner (Ed.), Precambrian Plate Tectonics, Elsevier, Amsterdam, 623-648.

Polkanow A. A. \& Gerling E. K., 1960. The Precambrian geochronology of the Baltic Shield. 21th Int. Geol. Congress, Precambrian stratigraphy and correlations, 183 -191 .

Raith M.; Raase P. \& Hormann P. K., 1982. The Precambrian of Finnish Lapland: Evolution and regime of metamorphism. Geol. Rundschau 71, 230-244.

Rastas P., 1980. Stratigraphy of the Kittilä area. In: A. Silvennoinen $(E d$.$) , Jatulian Geology of the eastern part of$ the Baltic Shield, Proc. Finnish-soviet Symposium, Rovaniemi, $145-152$.

Sederholm J. J., 1916. On synanthetic minerals and related phenomena. Bull. Comm. Geol. Finlande 48.

Shackelton R. M., 1973. Problems of the evolution of the continental crust. Phil. Trans. R. Soc. London A-273, $317-320$.

Shaw D. M., 1968. A review of K-Rb fractionation trends by covariance analysis. Geochim. Cosmochim. Acta 32, $573-601$

Silvennoinen $A$. (Ed.), 1980. Jatulian Geology of the eastern part of the Baltic Shield. Proc. Finnish-soviet symposium, Rovaniemi, $251 \mathrm{p}$.

Simonen A. \& Mikkola A., 1980. Finland. In: Geology of the European countries. 26th Int. Geol. Congress, Paris, Dunod, 55-130.

Sutton J. \& Watson J., 1974. Tectonic evolution of continents in early Proterozoic times. Nature 274, 433-435.

Svetov A. P., 1980. The Jatulian volcanism of Karelia. In: A Silvennoinen $(E d$.), Jatulian Geology of the eastern part of the Baltic shield, Proc. Finnish-soviet Symposium, Rovaniemi, 195-220.

Tarney J. \& Windley B. F., 1977. Crustal development in the Archean. IUGS-UNESCO-IGCP Symposium, Hyderabad, India, 117-119 (abstract).

Väyrynen H., 1933. Über die Stratigraphie der Karelischen Formationen. Bull. Comm. Geol. Finlande 101, 54-78.

Veizer J., 1973. Sedimentation in geologic history: Recycling vs. evolution or recycling with evolution. Contrib. Mineral. Petrol. 38, 261-278.

Vidal P.; Blais S.; Jahn B. M.; Capdevila R. \& Tilton G. R., 1980. U- Pb and $\mathrm{Rb}-\mathrm{Sr}$ systematics of the Suomussalmi Archean greenstone belt (eastern Finland). Geochim. Cosmochim. Acta 44, 2033-2044.

Williams H. R., 1977. African Archean mobile belts and granite-greenstone terrains. Nature 266, 163-164.

Windley B. F., 1981. Phanerozoic granulites. J. Geol. soc. London 138, 745-751.

Windley B. F. \& Smith J. V., 1976. Archean high-grade complexes and modern continental margins. Nature 260, 671-675.

Winkler H. G. F., 1976. Petrogenesis of metamorphic rocks. 4th edition, springer Verlag, New-York.

Wright A. E.; El Hiyari M. A.; Jackson A. J. \& Fediukova $E ., 1978$. The structural history and geochemistry of the Lapland granulites, Finland. In: A. V. Sidorenko (Ed.), Correlations of the Precambrian, Moscow, 223-235.

Zagorodnyi V. G., 1980. Jatulian geology of the Kola Peninsula. In: A. Silvennoinen (Ed.), Jatulian Geology of the eastern part of the Baltic Shield, Proc. Finnishsoviet Symposium, Rovaniemi, 221-235.

Zhuravlev V. A.; Ivanov N. M.; Negrutza V. Z.; Negrutza T. F. \& Pushkin G. J., 1980. Prejatulian formations of the link zone between Karelides and Belomorides. In: A. Silvennoinen ( $E d$.), Jatulian Geology of the eastern part of the Baltic Shield, Proc. Finnish-soviet Symposium, Rovaniemi, 239-251.

Zorin Y. A., 1981. The Baikal rift: An example of the intrusion of asthenospheric material into the lithosphere as the cause of disruption of lithospheric plate. Tectonophysics 73, 91-104.

Manuscript received, January 4, 1984. 